\title{
Intraplate Seamounts as a Window into Deep Earth Processes
}

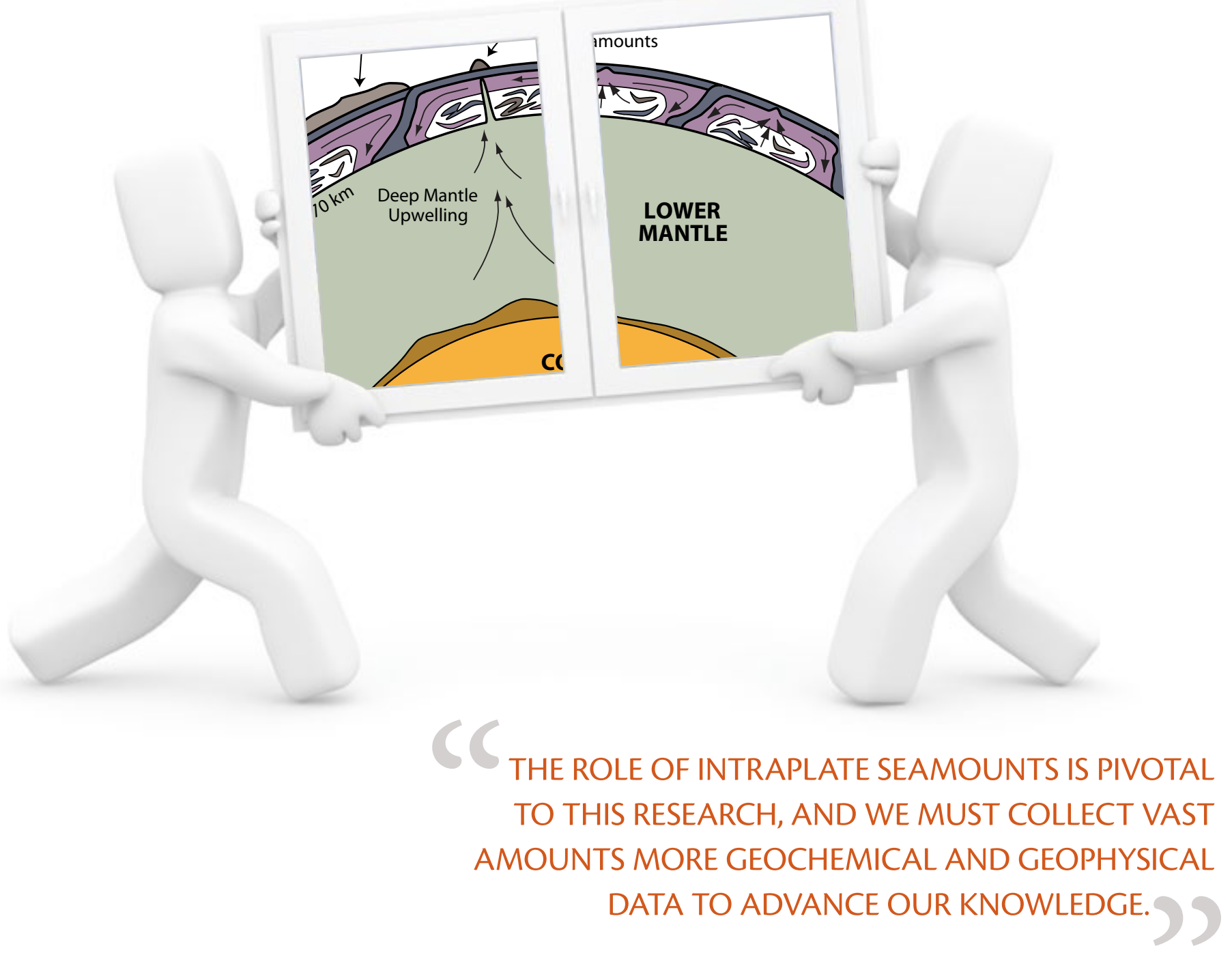


ABSTRACT. Seamounts are windows into the deep Earth that are helping to elucidate various deep Earth processes. For example, thermal and mechanical properties of oceanic lithosphere can be determined from the flexing of oceanic crust caused by the growth of seamounts on top of it. Seamount trails also are excellent recorders of absolute plate tectonic motions and provide key insights into the relationships among plate motion, plume motion, whole-Earth motion, and mantle convection. And, because seamounts are created from the partial melts of deep mantle sources, they offer unique glimpses into the chemical development and heterogeneity of Earth's deepest regions. Current research efforts focus on resolving the fundamental differences between magmas generated by passive upwelling from upper mantle regions and deep mantle plumes rising from the core-mantle boundary, mapping the different modes of mantle plumes and mantle convection, reconciling fixed and nonfixed mantle plumes, and understanding the prolonged volcanic evolution of seamounts. The role of intraplate seamounts is pivotal to this research, and we must collect vast amounts more geochemical and geophysical data to advance our knowledge. These data needs leave the ocean wide open for future seamount exploration.

\section{INTRODUCTION}

For centuries, scholars believed the ocean floor was featureless and without any significant topography. Seamounts, primarily of volcanic origin, were not discovered until the 1940s when US Navy ships using first-generation echosounders started to map the deep ocean floor of the Central Pacific (Hess, 1946). The discovery of seamounts and other seafloor topographic features, such as mid-ocean ridges, transform faults, and deep-sea trenches, ushered scientists into a new wave of ocean exploration, ultimately providing the key evidence needed to support the plate tectonics (Wilson 1965; McKenzie and Parker, 1967; Morgan, 1968; McKenzie and Morgan, 1969) and the hotspot and plume hypotheses (Wilson, 1963; Morgan, 1971). These scientific transformations placed marine geology and geophysics in a completely new geodynamical light and provided an impetus for seamount research. Today, we estimate that more than 200,000 volcanic oceanic islands, atolls, and seamounts are scattered over the ocean floor (Hillier and Watts, 2007), whereby the absolute number depends on the methods and minimum size cut-offs used in seamount counts (Wessel et al., 2010).

Seamounts offer a much-used window in our understanding of processes occurring in Earth's lithosphere and the mantle domain beneath. Through seamount research, key advances have been made in our understanding of (1) the thermal and mechanical properties of oceanic lithosphere, (2) the absolute plate tectonic motions and relationships among plate motion, plume motion, whole-Earth motion, and mantle convection, (3) the partial mantle melting in mid-plate settings, and (4) the chemical development and heterogeneity of the mantle. Together, these advances paint a picture of the "deep Earth" that is both complex and strongly dynamic. In this review, we summarize the latest discoveries and outstanding questions in seamount research, giving an overview on (1) how intraplate seamounts are derived from mantle plumes, smallerscale plumelets, or plate extension, (2) how these seamounts fit within the plate tectonic context, (3) what they tell us about the physical state of a tectonic plate, and (4) how their geochemistry relates to global mantle geodynamics. From these insights, it becomes clear that a more systematic approach to intraplate seamount exploration will be crucial in the future if we are to gain a more complete understanding of the geodynamical aspect of Earth, today and over the geological past.

\section{MANTLE PLUMES, PLUMELETS, AND PLATE EXTENSION}

Volcanic islands (e.g., Hawai' i, Cape Verdes, and Réunion) and seamounts typically form far away from plate tectonic boundaries where more than 95\% of Earth's volcanic activity occurs. To explain this so-called intraplate volcanism in the context of plate tectonics, mechanisms other than subduction, seafloor spreading, and transform faulting are required. Thus, following on the heels of the plate tectonic revolution in the 1960s, it was proposed that seamount trails are the surface expressions of buoyantly rising "hot" mantle plumes (Figure 1) originating deep in Earth's mantle (Morgan, 1971). In the now classic "hotspot" model, mushroom-shaped plume heads are believed to cause the formation of voluminous large igneous provinces (e.g., flood basalts, oceanic plateaus) on the surface of the overriding tectonic plates when they impinge on the base of the lithosphere and flatten out (Griffiths and Campbell, 1991). These impingements also mark the beginnings of narrow 

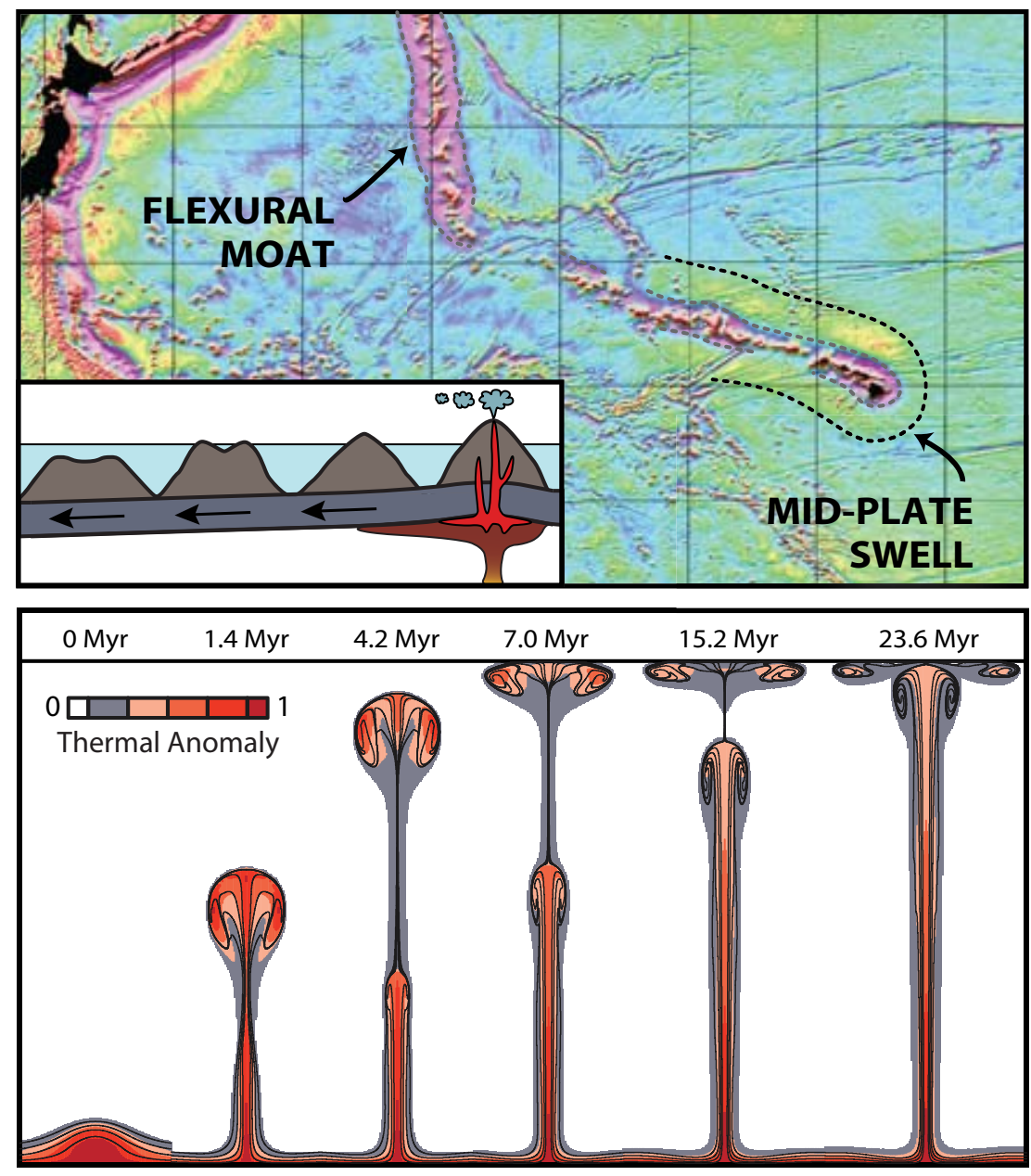

Figure 1. The Hawaiian-Emperor hotspot trail is our textbook example of the classical mantle plume model explaining the formation of intraplate seamounts. In this map of the Northwest Pacific (D. Sandwell and W.M. Smith: Gravity Anomaly Map based on Satellite Altimetry, Version 15.2), this archetypical seamount trail is exemplified by a deep flexural moat along its entire length and a significant mid-plate swell only prevalent toward the young southeastern end. The linearity of this seamount trail, in combination with a large mid-plate swell and a systematic age progression (with radiometric ages increasing toward the older northwestern end; see Figure 2), provides strong evidence for the existence of a mantle plume, maybe originating deep in the mantle from a thermal anomaly (see simulation at the bottom by Van Keken [1997]). In this model, the seamount trail only forms after the plume head has dissipated and the narrow plume stem starts interacting with the lithosphere. Because the older Emperor seamounts have all been subducted into the Aleutian trench to the north, the fate of the plume head and any link to large igneous province volcanism are unidentified.

(more or less linear) seamount trails that form as the plates constantly move over the "fixed" loci of the upwelling mantle plume stems (Richards et al., 1989).

Many observations are consistent with the existence of mantle plumes. Large mid-plate topographic swells (typically 1500-3000-km wide, up to 1500-m high, and correlating with longwavelength gravity and geoid anomalies) have been found at the leading edges of many active seamount trails. The correlation implies that the swells are supported at depth by low-density subcrustal mantle material. This large-scale warping of otherwise rigid lithosphere is most noticeable for the Hawaiian-Emperor seamount trail (e.g., Watts, 1976) and is believed to be directly related to the buoyancy of a plume and its interaction with the overlying Pacific Plate (Figure 1). Mapping of these swells using satellite-derived gravity and geoid data, for instance, allowed scientists to equate the sizes of these swells to vertical plume fluxes. Although the volume of active intraplate volcanism is small compared to island arc volcanism and the formation of the oceanic crust at the mid-ocean ridges, plume fluxes ranging from $1.0 \mathrm{Mg} \mathrm{s}^{-1}$ (Canary) to 8.7 $\mathrm{Mg} \mathrm{s}^{-1}$ (Hawai ${ }^{\mathrm{i}}$ ) become significant when integrated over geological time and including all known hotspot systems (Davies, 1988; Sleep, 1990). Further observations that support the presence of mantle plumes include evidence that these lithospheric swells diminish away from active hotspots, the formation of linear age-progressive seamount trails, and the volcanic extinction of seamounts when plate motions move them away from their hotspot locations.

But mantle-plume behavior is not quite so simple, as the latest numerical mantle convection models suggest that a simple density-driven upwelling (Figure 1) is very unusual (but not implausible) and that the resulting plumes mostly are not vertically straight, narrow, and continuous, but often

Anthony A.P. Koppers (akoppers@coas. oregonstate.edu) is Associate Professor, College of Oceanic and Atmospheric Sciences, Oregon State University, Corvallis, OR, USA. Anthony B. Watts is Professor of Marine Geology and Geophysics, Department of Earth Sciences, University of Oxford, Oxford, UK. 
inclined, plump, and broken up over their lengths (e.g., Steinberger and O'Connell, 1998; Steinberger, 2000; Farnetani and Samuel, 2003; Davaille and Vatteville, 2005; Lin and van Keken, 2006b; Davies and Davies, 2009). Over time, these simulated mantle plumes swell up, narrow down, thin out, split up, stagnate at different depths, show pulsating behavior, or shoot off as small plumelets from giant superplumes

(Figure 2). None of these predicted behaviors have been corroborated in the field, but a more "dynamic" (maybe even chaotic) behavior of plumes in an overall convecting mantle is not unexpected, in particular with domains variable in composition (peridotite vs. eclogite) and temperature (hot vs. less hot). However, individual plumes are difficult to image by seismological techniques, mostly because the $\sim 100-\mathrm{km}$ mantle plume stems are too narrow for the current resolution of mantle tomography (e.g., Nataf, 2000; Montelli et al., 2006). Even though seismologists are close to achieving this resolution, the outcome and interpretation of "plume tomography" is still rather contentious. A largescale experiment, including a network of seafloor and land-based seismometers, now provides three-dimensional images of the Hawaiian mantle plume as deep as $1,500 \mathrm{~km}$ in the Pacific mantle, based on anomalies in seismic shear-wave velocities that are several hundred kilometers wide and mostly interpreted as resulting from an upwelling hightemperature plume (Wolfe et al., 2009). Further development of these techniques is critical if we are ever to verify the numerical convection models and to learn about different plume modes and shapes. Until then, studying seamounts and their associated topographic swells, which are the only tangible surface products of mantle plumes, remains crucial in corroborating the different mantle plume simulations and models.

Present-day evidence suggests it is likely that more than one type of plume or hotspot exists in Earth's mantle.

Primary hotspots (Courtillot et al., 2003) are few and far between and consist of long-lived, voluminous, and age-progressive seamount trails, like the HawaiianEmperor (Figure 1) and Louisville ridges. Secondary hotspots such as Pitcairn, Samoa, and Tahiti are short-lived and much less voluminous (Courtillot et al., 2003), yet they form the majority of the seamount trails in the Pacific (Koppers et al., 2003). Where primary hotspots are thought to be formed over deep and strong mantle plumes, secondary hotspots are weak and could be interpreted to represent off-shoots from so-called superplumes, which themselves are stagnating at the bottom of the upper mantle. Tertiary hotspots are unrelated to deep mantle plumes (Courtillot et al., 2003) and are thought by some to be the volcanic products of plate processes associated with (subduction-induced)

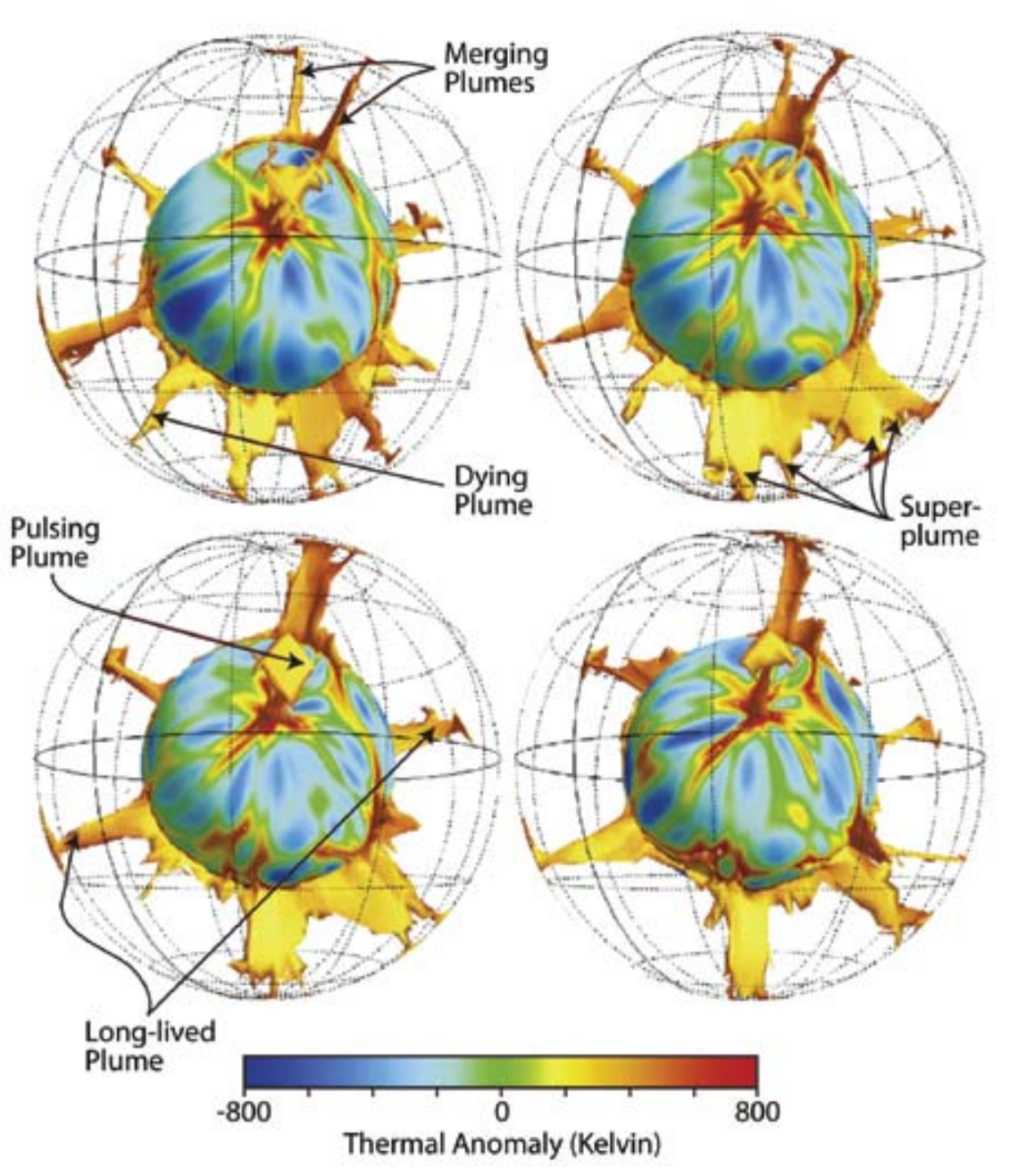

Figure 2. Example of "dynamic" (or even chaotic) modeled mantle plume behavior by Davies and Davies (2009), showing evidence for a variety of plume types. 
extensional “cracks." Alternate geodynamic models, therefore, have been proposed to explain the formation of tertiary trails (e.g., Foulger and Natland, 2003; Natland and Winterer, 2005) or to clarify complications observed in the data of primary and secondary hotspot trails (e.g., Koppers and Staudigel, 2005; Koppers et al., 2008).

One of the first seamount trails for which an alternative (i.e., not a mantle plume) explanation was offered was Puka Puka Ridge in the south-central Pacific (Winterer and Sandwell, 1987; Sandwell et al., 1995). This tertiary hotspot formed an elongate volcanic ridge that is located on oceanic crust with a low elastic thickness and is aligned in the direction of Pacific absolute plate motion (Goodwillie, 1995). Consequently, this seamount trail was not attributed to classical hotspot volcanism, but rather to small-scale mantle convection occurring directly below the lithosphere, cracking of the lithosphere, or thermal contraction occurring orthogonal to the direction of an aging and cooling oceanic plate (Sandwell et al., 1995; Sandwell and Fialko, 2004). In any case, in these alternate models, the source of volcanism is envisioned to lie decidedly in the upper mantle, compared to the presumed lower mantle origins of mantle plumes. However, Puka Puka Ridge is not a unique feature; it is part of a larger region in the south-central Pacific characterized by an anomalously high level of active intraplate volcanism, anomalously thin elastic plate thicknesses, seismic tomographic evidence of diffuse upwelling, and abundant extensional features (e.g., McNutt, 1998; Forsyth et al., 2006; Clouard and Gerbault, 2008). The question remains whether the seamounts of
Puka Puka Ridge, and tertiary hotspots in general, are formed by hotspot volcanism, plate extension, or some combination of these mechanisms acting at different times in the geological past. Over the last decades, these generally small tertiary hotspot trails often have been neglected, as they remain poorly surveyed and sampled.

\section{SEAMOUNTS IN A PLATE TECTONIC CONTEXT}

Seamount trails associated with active and historical volcanoes (e.g., Hawai' i, Society, or Walvis ridges) have been interpreted as age-progressive traces reflecting the absolute motion of tectonic plates with reference to an assumed long-lived system of stationary hotspots (Morgan, 1971, 1972; Muller et al., 1993; Wessel and Kroenke, 2008). Radiometric age dating of these long-lived, continuous seamount trails typically illustrates systematic progression in measured seamount ages, getting increasingly older away from the active volcanoes (Figure 3). It was noted early on that these "recording tracks" of hotspot volcanism are consistent (and mostly linear in space and time) for seamount trails having equivalent orientations on a single tectonic plate and that they could be used to derive the ancient "absolute" motions of the tectonic plates (e.g., Morgan, 1972; McDougall and Duncan, 1980). The absolute motions are, in principle, independent of the "relative" motions between plates and can be as fast as $10 \mathrm{~cm} \mathrm{yr}^{-1}$, as confirmed by presentday GPS measurements. Also, it was observed that the orientation of some of these seamount trails changes over time, apparently recording a change in the direction of plate motion with respect to the stationary hotspots. In these cases, the absolute plate motion models for a particular plate require multiple sets of rotation parameters (i.e., with different plate rotation poles and angular plate velocities) to describe the different directions of plate motion during different time intervals. The sharp $120^{\circ}$ bend in the orientation of the Hawaiian-Emperor seamount trail, which formed between 50 and 44 million years ago (Sharp and Clague, 2006), is the textbook example of such a likely change in plate motion (Figure 3), even though new evidence shows that the assumption of stationary mantle plumes may not hold true for most seamount trails (e.g., Cande et al., 1995; Koppers et al., 2001; Koppers and Staudigel, 2005).

Paleomagnetic evidence shows that seamounts in the oldest part of the Hawaiian-Emperor seamount trail formed at paleolatitudes $\sim 15^{\circ}$ north of the current location of the Hawaiian hotspot (Tarduno et al., 2003, 2009), indicating that the mantle plumes themselves may move centimeters per year, which is the same order of magnitude as velocities for plate motion (Figure 4). In addition, processes such as plate extension, lithosphere cracking, and small-scale shallow-mantle convection may be important in the formation or overprinting of some of the primary and secondary trails, resulting in complex age systematics that sometimes may appear erratic or nonlinear (Foulger and Natland, 2003; Koppers et al., 2003, 2007, 2008; Koppers and Staudigel, 2005; O’Connor et al., 2007). Employing seamount trails to derive past plate motions using a "fixed reference frame" of mantle plumes thus is becoming much more complicated and now requires 


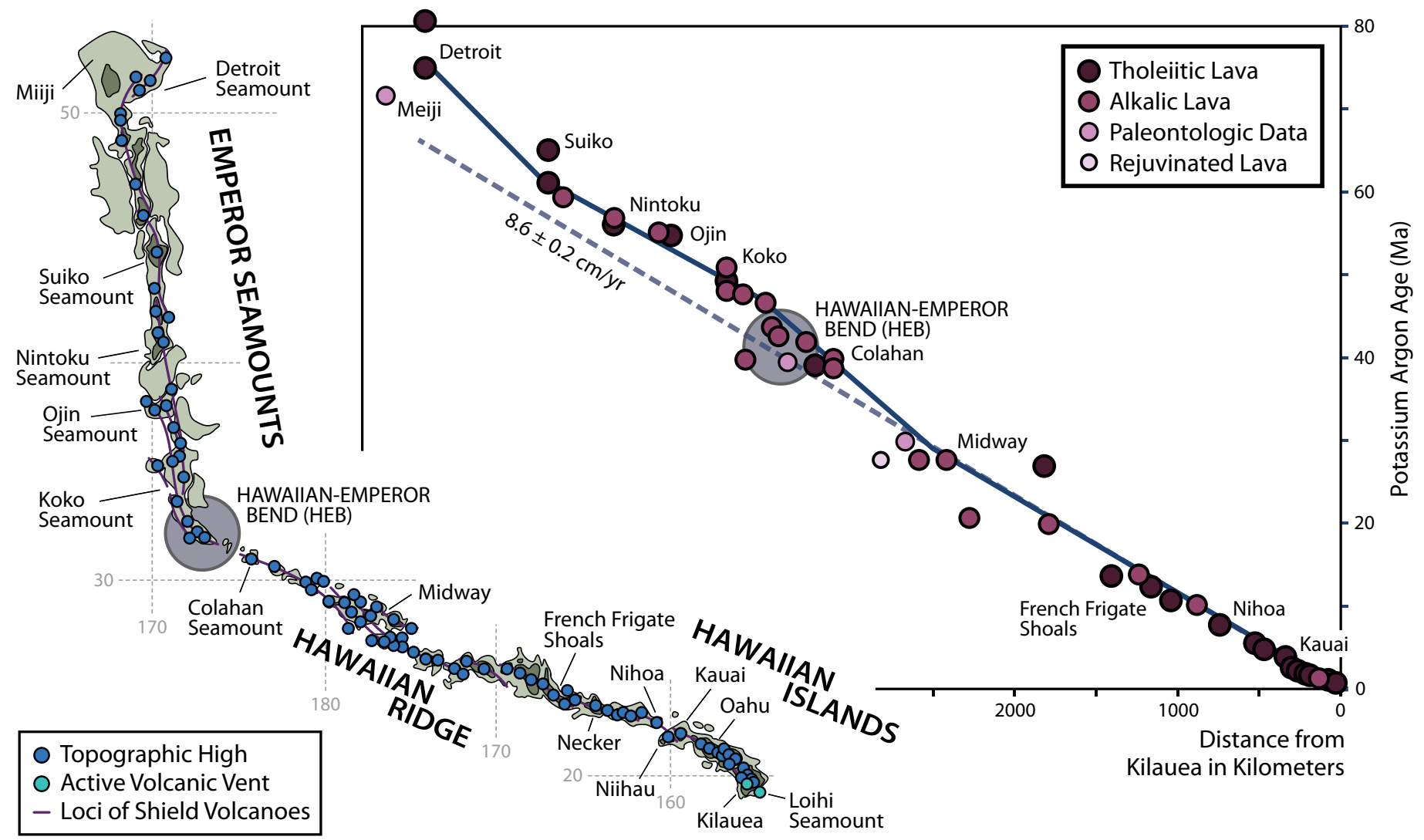

Figure 3. Linear Hawaiian age progression derived from ages of Hawaiian-Emperor seamounts plotted against their distance from the active Kilauea Volcano based on data available from Clague and Dalrymple (1987), Duncan and Keller (2004), and Sharp and Clague (2006). Although the highly linear morphology of this seamount trail is more intricate when viewed close up (Jackson et al., 1972), these K/Ar and ${ }^{40} \mathrm{Ar} /{ }^{39} \mathrm{Ar}$ age data show a systematic (and more or less linear) aging of the shields of these volcanic islands and seamounts to the northwest and across the sharp $120^{\circ}$ Hawaiian-Emperor Bend (HEB).

knowledge about the motion of the plumes themselves as well as the best possible seamount geochronology.

Recent improvements in ${ }^{40} \mathrm{Ar} /{ }^{39} \mathrm{Ar}$ geochronology have allowed us to start addressing many of the above-described challenges in hotspot geodynamics and intraplate volcanism. Sensitivity improvements in mass spectrometry and the construction of low-blank extraction lines, in combination with aggressive application of incremental heating protocols, have allowed a renaissance in the age dating of seamounts (e.g., Koppers et al., 2003, 2007, 2008; Sharp and Clague, 2006; O'Connor et al., 2007). As a result, a more precise understanding of the timing of intraplate volcanism has allowed us to accurately determine durations of seamount formation (sometimes up to $\sim 10$ million years) and rates of age progression along seamount trails. Even though early geochronological studies squarely underwrote the hotspot model, later studies (for the same or other seamount trails, based on more extensive data sets, and using today's analytical techniques) have revealed a significantly more complicated picture. For example, age dating and paleomagnetic data from Ocean Drilling Program (ODP) Leg 197 demonstrated that the Hawaiian hotspot drifted south from $\sim 35^{\circ} \mathrm{N}$ to $20^{\circ} \mathrm{N}$ between 80 and 49 million years ago (Figures 3 and 4; Tarduno et al., 2003; Duncan and
Keller, 2004; Duncan et al., 2006). The direction and magnitude of this drift is similar to recent modeling of plume advections within the context of whole mantle convection (Koppers et al., 2004; Steinberger et al., 2004) and suggests that initiation $\sim 50$ million years ago of the distinctive $120^{\circ}$ Hawaiian-Emperor Bend (HEB) partially or even entirely reflects a change in the timing and magnitude of hotspot motion (Steinberger and O'Connell, 1998; Tarduno et al., 2003, 2009; Steinberger et al., 2004). Redating of the Louisville seamount trail (Koppers et al., 2004) has shown that a formerly "linear" age progression (Watts et al., 1988 ) is, in fact, nonlinear, with variations in both hotspot and plate motions, 


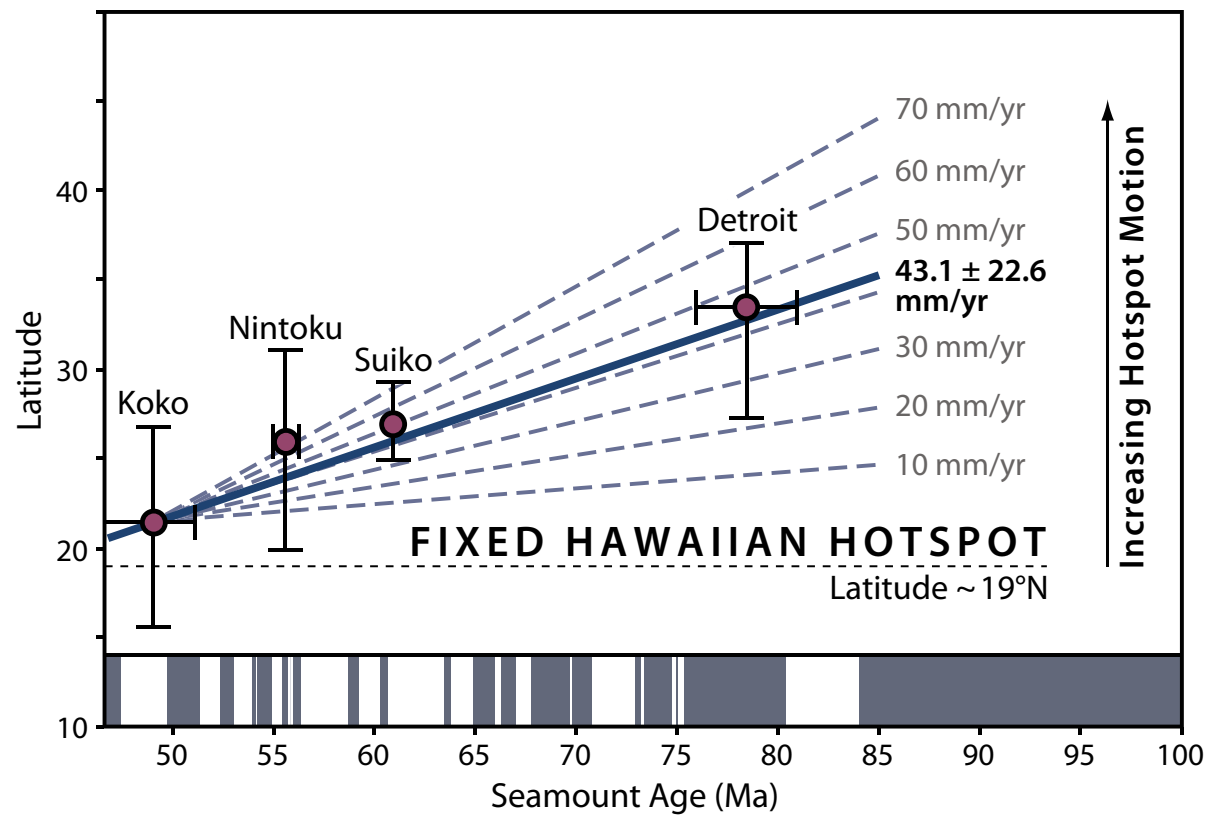

Figure 4. Plume motion of the Hawaiian hotspot becomes apparent in paleomagnetic data, showing an estimated $\sim 15^{\circ}$ southern motion between 80 and 50 million years ago, when comparing the measured paleolatitudes with the current latitude of the Hawaiian hotspot at $19^{\circ} \mathrm{N}$ (Tarduno et al., 2003). By applying a linear regression through the paleolatitude data from Detroit, Suiko, Nintoku, and Koko seamounts, a hotspot motion of approximately $43 \pm 23 \mathrm{~mm} \mathrm{yr}^{-1}$ is estimated. As Koko has a paleolatitude close to $19^{\circ} \mathrm{N}$, it has been argued that the Hawaiian hotspot motion between 50 million years ago and the present day is minor.

which raises the question whether the Louisville hotspot has been moving in a similar fashion as the Hawaiian hotspot. The latest mantle convection simulations seem to suggest that Louisville hasn't moved south nearly as much as Hawai ' $i$, as the "mantle wind" seems to predominantly blow from west to east in the southwest quadrant of the Pacific (Steinberger and Antretter, 2006). Other hotspot trails show either no or complex age progressions (Davis et al., 2002;

Koppers et al., 2003), have Hawaiiantype bends that predate the HEB by 10 to 20 million years (Koppers and Staudigel, 2005; Koppers et al., 2007), or in general have age progressions incompatible with existing plate rotation models (Koppers et al., 1998, 2001). On the other hand, new studies on Samoa (Koppers et al., 2008), Easter Island and the
Sala Y Gomez Ridge (Robert A. Duncan, Oregon State University, pers. comm., 2009), the Emperor Seamounts (Duncan and Keller, 2004; Sharp and Clague, 2006), and the Louisville Ridge (Lindle et al., 2008) show that these seamount trails possess linear age progressions, providing us with supporting evidence for typical primary hotspot systems in the Pacific.

\section{THE PHYSICAL STATE OF A TECTONIC PLATE INCLUDING SEAMOUNTS}

During the past few decades, there has been a significant increase in our understanding of the deep structure of seamounts and oceanic islands as well as the lithosphere that underlies them. Seismic refraction data acquired along transects of the Hawaiian Ridge
(Watts and ten Brink, 1989), Josephine Seamount (Peirce and Barton, 1991), Marquesas Islands (Caress et al., 1995), Canary Islands (Watts et al., 1997; Ye et al., 1999), Réunion (Charvis et al., 1999), Great Meteor Seamount (Weigel and Grevemeyer 1999), and, most recently, Cape Verde Islands (Pim et al., 2008) and Louisville Ridge (ContrerasReyes et al., 2010) show that seamounts and oceanic islands have built upward and outward on top of the oceanic crust by up to $\sim 8 \mathrm{~km}$ and $\sim 100 \mathrm{~km}$, respectively. The flanks (and sometimes the tops) of seamounts typically consist of volcanic lithologies that tend to impede the propagation of elastic P-wave velocities, whereas the same kind of seismic waves travel much faster through the cores of these structures. For example, a "fan-shoot" seismic experiment around Tenerife (Canary Islands) revealed velocities (Figure 5 ) significantly higher $\left(7.3 \mathrm{~km} \mathrm{~s}^{-1}\right)$ than expected for young basaltic lavas and suggests that an old intrusive and plutonic complex is at core of this volcano (Canales et al., 2000). Seismic refraction data also show that the crust underlying the volcanic edifices of Oahu (Hawaiian Ridge), Marquesas Islands, Réunion, and Great Meteor Seamount have velocity structures and thicknesses typical of normal oceanic crust. Remarkably, there is little lateral variation in these crustal velocities, indicating that magmatic material originating deep in and below the lithosphere must migrate vertically through the oceanic crust with little or no lateral sill-like intrusion (see also Staudigel and Clague, 2010). The oceanic crust itself, however, is often underlain by a highvelocity lower crustal body (i.e., faster than $7.2 \mathrm{~km} \mathrm{~s}^{-1}$ ). These lower crustal 
bodies have been interpreted as material that, rather than intruding into the oceanic crust, has spread laterally and is underplating the crust (Watts et al., 1985; Caress et al., 1995; Weigel and Grevemeyer, 1999). Unfortunately, we know little of the composition of this material (it has never been sampled) or its role in the dynamical support of seamounts, seamount trails, and their associated large-scale mid-plate topographic swells.

On a much smaller scale, extrusive basalts and intrusive plutonic rocks that make up a seamount structure represent a significant gravitational load on the surface of the oceanic crust. Upon loading, the crust may bend (or flex) and form deep, wedge-shaped moats that are in-filled by volcaniclastic material (Figures 1 and 5). Comparisons of the deep seismic structure of seamounts to calculations based on elastic plate models for Hawai' i, for example, show that volcano loading has flexed the oceanic crust downward by up to $4 \mathrm{~km}$ over horizontal distances of up to a few hundreds of kilometers (e.g., Watts et al., 1985). The general view to have emerged from oceanic flexure studies is that the elastic thickness $T_{e}$ (Figure 5) depends on both the age of loading and plate age at that time. Lithosphere strength increases with age as it cools away from a mid-ocean ridge, in such a way that "on-ridge" seamounts flexing young lithosphere have a thinner elastic thickness than the same-sized "off-ridge" volcano emplaced on older lithosphere. In addition, oceanic flexure studies show that the lithosphere is relatively strong during initial volcano loading and becomes weaker as a seamount ages (Watts and Zhong, 2000). There is, therefore, a competition between
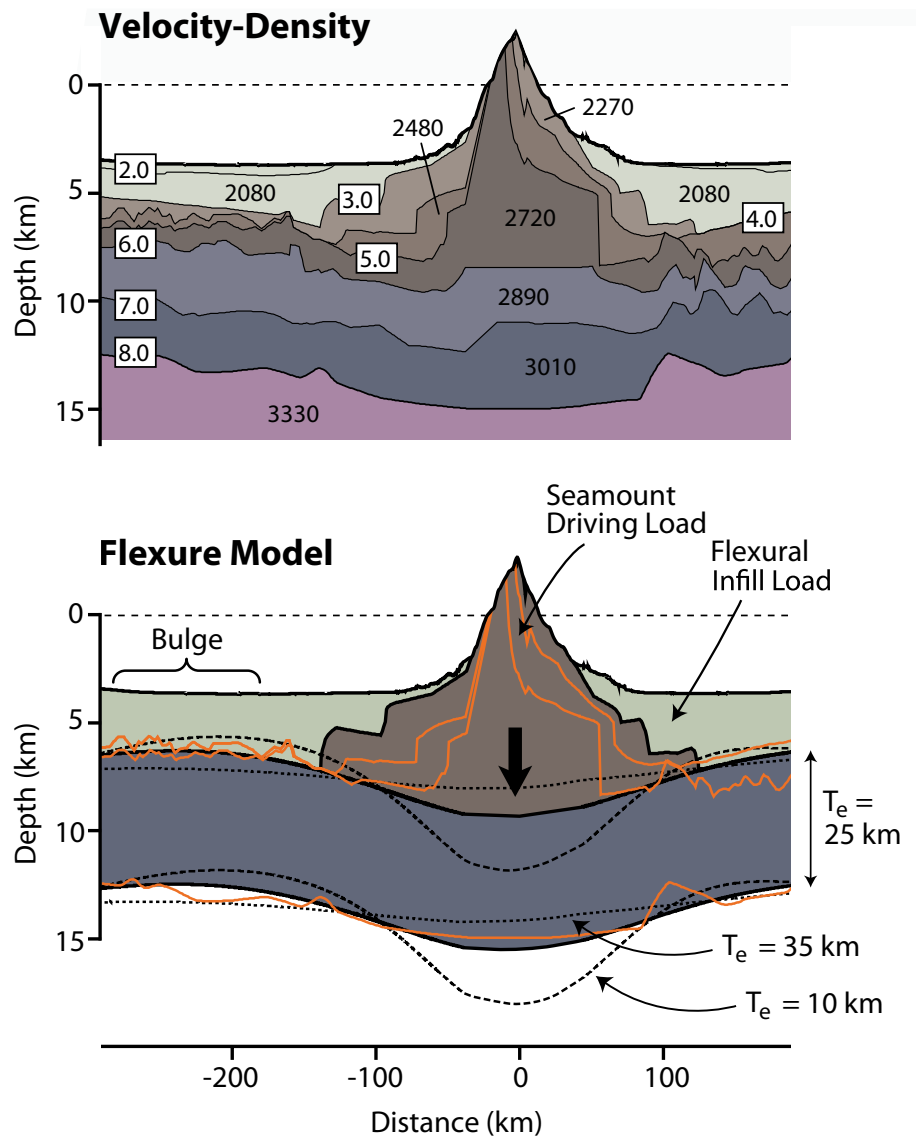

Free-Air Gravity Anomaly

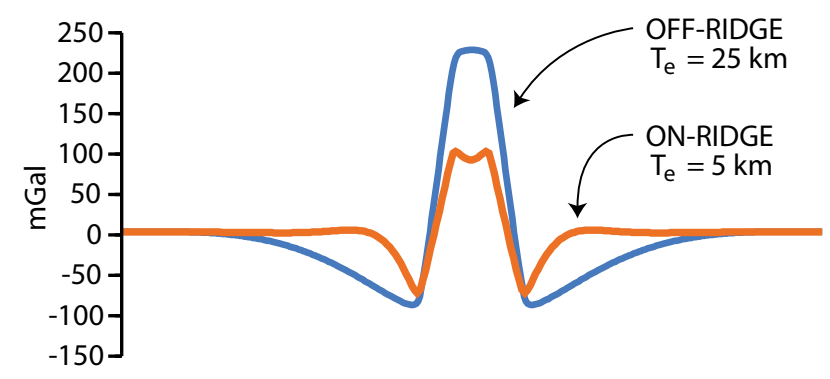

Crustal Structure Cartoon

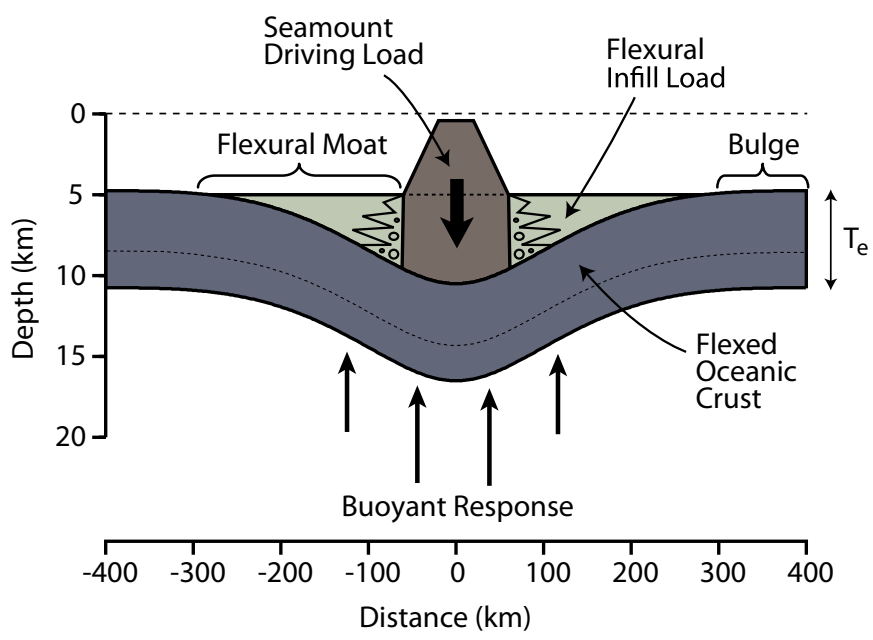

Figure 5. Example data from Tenerife (Watts et al., 1997) showing a typical seismic velocity (in $\mathrm{km} \mathrm{s}^{-1}$ ) and density model (in $\mathrm{kg} \mathrm{m}^{-3}$ ) of the Atlantic oceanic crust in the Canary Islands. The sediment infill of the flexural moat (light green color) is clearly indicated by low velocities and low densities, whereas mantle rocks in the asthenosphere (purple color) are recognized by high seismic velocities and high rock densities. Flexural modeling provides a robust estimate of $T_{e}=25 \mathrm{~km}$ (dark gray color) with no additional magmatic underplating necessary. The cartoons on the right explain the concept of lithospheric flexure upon the loading of an oceanic lithosphere by a seamount (and the volcanic sediments they generate in their aprons) and the calculation of elastic plate thickness $T_{e}$ that provides a measure for both the strength and thermal character of a flexed oceanic crust. Modified after Hillier (2007) 
thermal contraction that strengthens lithosphere during its cooling and loadinduced stress relaxation that weakens it. The net effect is for the oceanic lithosphere to strengthen with age. These spatial and temporal changes in strength have important implications for the rheology of oceanic lithosphere and how it responds to other forces, such as vertical stresses associated with (upward) mantle flow (at hotspots, for example). Seamounts and oceanic islands, especially the stratigraphy of their flanking moats, thus offer us a unique way to examine these changes as seamounts and seamount trails evolve. In fact, based on gravity anomaly data from satellite altimetry, we can create distribution maps showing where typical "on-ridge" and "off-ridge" seamounts were emplaced (Figure 6). Also, many seamounts are superimposed on longwavelength topographic swells, so elastic thickness (which is a proxy for temperature) is pertinent to understanding their origin as well (Figure 1). An anomalously low elastic thickness in these topographic swells would indicate lithospheric thinning and heating consistent with a mantle plume, while a normal elastic thickness would favor a model in which swells are dynamic features that originate by vertical motions associated with mantle flow (McNutt, 1984). Interestingly, Bermuda and Cape Verde both exhibit normal $T_{e}$ for their ages
(Sheehan and McNutt, 1989; Ali et al., 2003). This observation could indicate an increased component of dynamic support (i.e., vertical plume motion) in the formation of these mid-plate topographic swells.

Another proxy that might help elucidate the thermal structure of swells is surface heat flow measurements around seamounts. High heat flow could indicate lithospheric thinning and heating in association with sublithospheric temperature anomalies caused by mantle plumes. For example, the Bermuda, Cape Verde, and Hawaiian swells are each associated with small-amplitude heat flow highs (Von Herzen et al., 1982; Courtney and White, 1986; Detrick

\section{ON-RIDGE}

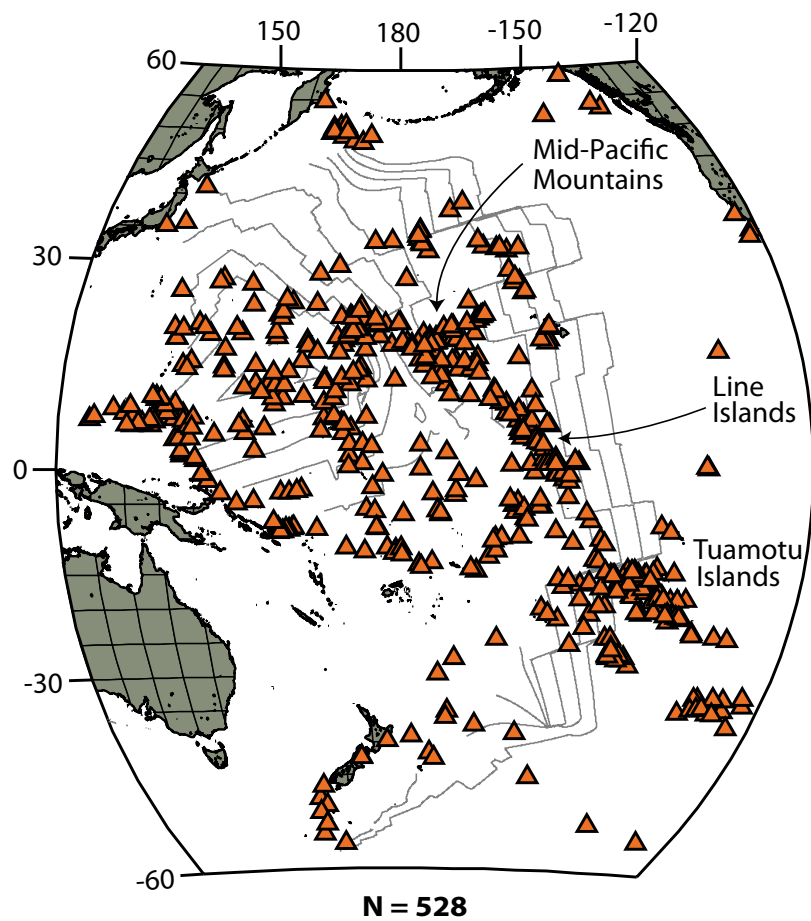

\section{OFF-RIDGE}

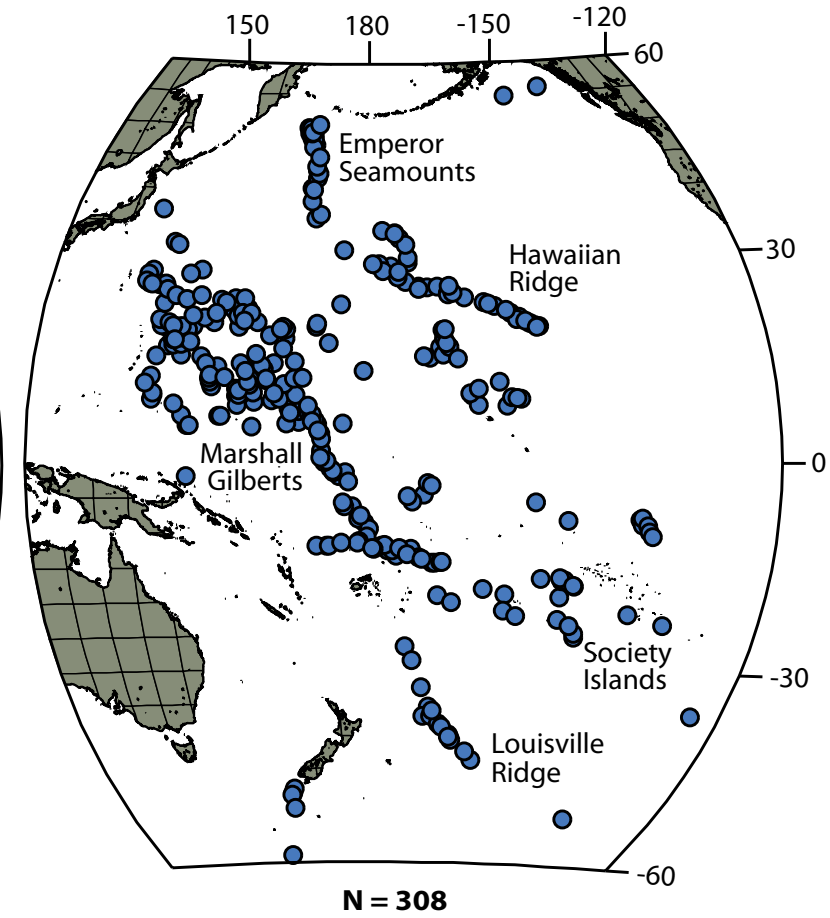

Figure 6. Distribution map of "on-ridge" vs. "off-ridge" seamounts based on gravity and flexure modeling (Watts, 2001; Watts et al., 2006). Elastic thickness $T_{e}$ is one parameter that is sensitive to whether a seamount formed nearby or far away from a mid-ocean ridge, as it is a proxy for the long-term strength and age of oceanic lithosphere. Using satellite-derived gravity anomaly data, Watts et al. (2006) could make $9758 T_{e}$ estimates in the Pacific, Indian, and Atlantic oceans combined. These $T_{e}$ estimates then could be assigned a tectonic setting in which the seamounts presumably formed, whereby $T_{e}$ estimates $<12 \mathrm{~km}$ are typical for seamounts formed on top of young "on-ridge" oceanic crust, and estimates $>20 \mathrm{~km}$ are typical for seamounts formed on older and thicker oceanic crust in "off-ridge" or true "intraplate" tectonic settings. 
et al., 1986), yet large local variations are observed when higher-resolution surveys are carried out, perhaps indicating that heat flow is controlled by fluid flow (Harris and McNutt, 2007). In the latter scenario, the fluids associated with the large relief of submarine volcanic edifices (see also Fisher and Wheat, 2010) and their flanking flexural moats might prevent the basal heat flow (originating in the upper mantle) from being measured, and that may obscure the full magnitude of any heating caused by a plume, if present.

\section{SEAMOUNT GEOCHEMISTRY}

\section{AND MANTLE GEODYNAMICS}

The proposed mantle plume source for intraplate seamounts and volcanic islands make them the ultimate geochemical window for detecting deep mantle domains (e.g., Hart et al., 1973; White et al., 1976; Allègre, 1982; Hofmann and White, 1982; McKenzie and O'Nions, 1983; Hawkesworth et al., 1984; Zindler and Hart, 1986) and for constraining different regimes of mantle convection (e.g., Galer and O’Nions, 1985; Allègre and Turcotte, 1986; Albarede and van der Hilst, 2002). As radiogenic isotopes (Figure 7) and highly incompatible trace element ratios can be used to trace and fingerprint various mantle components being recycled at subduction zones (see Hofmann, 2003, for a review), scientists nowadays know the mantle to be remarkably heterogeneous in character. As a result, various "marble-cake" and "multilayered" mantle models have been proposed (Figure 8). From this knowledge, a new field in geochemistry called "chemical geodynamics" (Allègre, 1982; Zindler and Hart, 1986) emerged, which is still developing and which is focusing on the evolution of the mantle reservoirs over geological time, the length scale of mantle heterogeneities, and the differentiation of Earth as a whole (e.g., Keller et al., 2004; Boyet and Carlson, 2006; Konter et al., 2008).

Intraplate seamounts, and the subaerial parts of volcanic islands, provide key geochemical data to study these
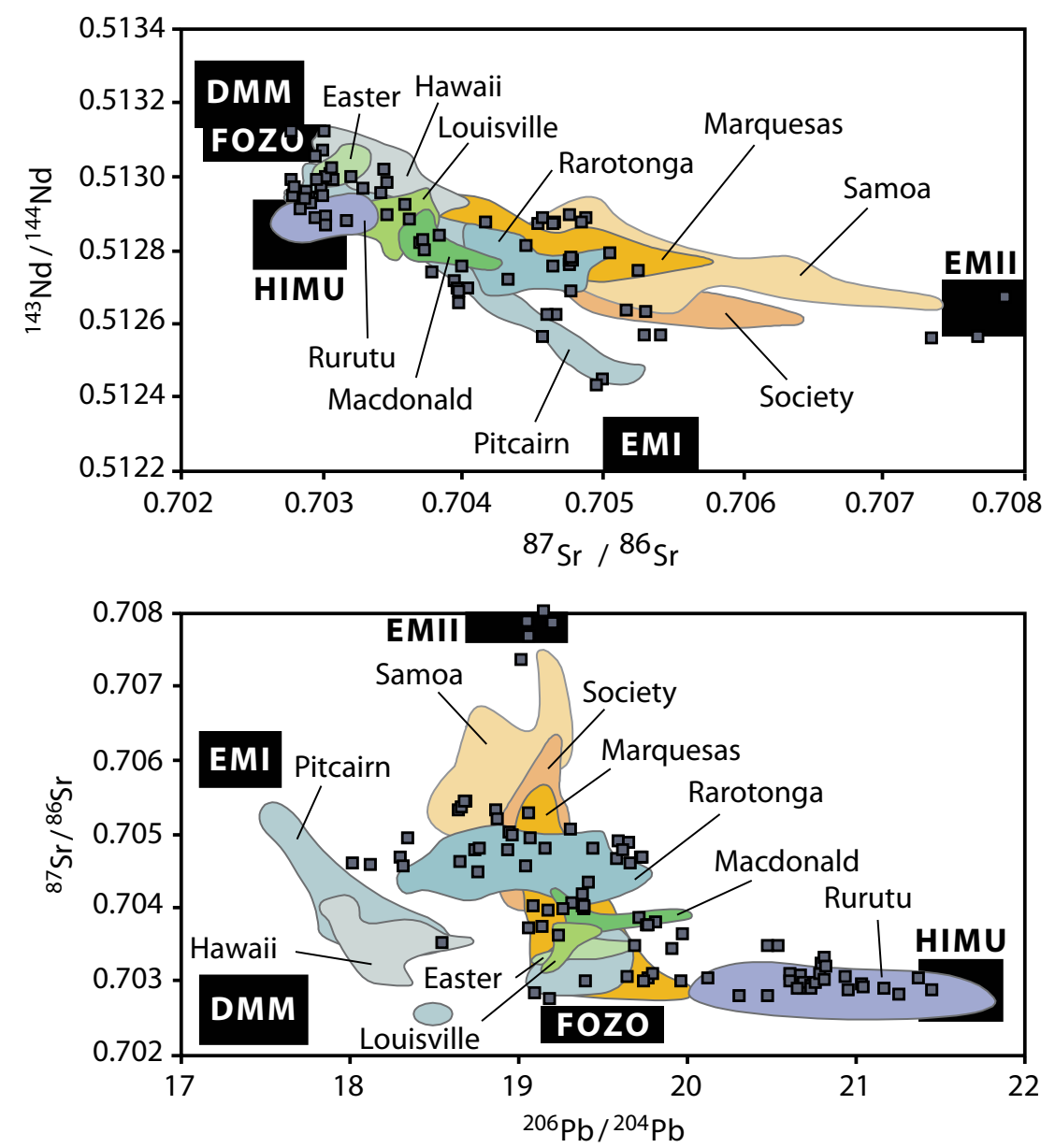

Figure 7. ${ }^{143} \mathrm{Nd} /{ }^{144} \mathrm{Nd}$ vs. ${ }^{87} \mathrm{Sr} /{ }^{86} \mathrm{Sr}$ and ${ }^{87} \mathrm{Sr} /{ }^{86} \mathrm{Sr}$ vs. ${ }^{206} \mathrm{~Pb} /{ }^{204} \mathrm{~Pb}$ isotope correlation diagrams showing ocean island basalt (OIB) and a selection of possible mantle end members (following Zindler and Hart, 1986; Hart et al., 1992). DMM is the depleted MORB mantle end member, which is regarded as the dominant upper mantle source upwelling beneath mid-ocean ridges. $\mathrm{EMI}$ is the first enriched mantle end member injected back into the mantle through the subduction process. This particular end member is likely to be recycled subcontinental lithospheric mantle that subsequently also has been altered by the interaction of $\mathrm{CO}_{2}$-rich fluids (i.e., metasomatized) while in the mantle. EMII is the second enriched mantle end member that commonly is equated to the recycling of pelagic sediment that forms on top of the oceanic crust in the open ocean environment. HIMU is a mantle end member that today is characterized by a high ${ }^{206} \mathrm{~Pb} /{ }^{204} \mathrm{~Pb}$ or " $\mu$-ratio" due to its isolation in the mantle for long periods of time and a high ${ }^{238} \mathrm{U} /{ }^{204} \mathrm{~Pb}$ ratio in the source rocks. Typically, this end member is believed to be recycled, altered oceanic crust. FOZO is the focal zone component and appears in the "center" or "focal point" of all isotopic data shown in both diagrams. Whether or not FOZO is a "real" component present in the mantle is still under debate, yet most seamount trails and ocean island provinces show data arrays pointing toward FOZO. 
geodynamical issues. However, basalts sampled there are geochemically different from basalts sampled along mid-ocean ridges or in island arcs. For example, seamount and ocean island basalts (OIB) differ from mid-ocean ridge basalts $(\mathrm{MORB})$ as they are more enriched (or less depleted) in rare earth and incompatible elements (e.g., Hart, 1971; Zindler and Hart, 1986). OIB also show significantly larger variations in isotope and trace element compositions (e.g., Staudigel et al., 1991). Whereas MORBs are assumed to sample a depleted and homogeneous upper mantle left after the prolonged extraction of continental material in the early Earth (e.g., Jacobsen and Wasserburg, 1979; Galer and O'Nions, 1985; Hawkesworth and Kemp, 2006), OIB require a smaller degree of partial melting in a deeper asthenospheric melting zone from a less-depleted (but heterogeneous) mantle source. It is generally believed that mantle plumes are the latter OIB source, either originating at the $660-\mathrm{km}$ mantle discontinuity or at the core-mantle boundary, depending on the adopted mantle convection model (Figure 8). However, a single source for all mantle plumes (i.e., from a compositionally similar "region" of the mantle) cannot possibly explain the large geochemical variations seen in OIB. In fact, their chemical signatures require at least two or more different enriched mantle components in the source for each individual seamount trail; these components are believed to originate from subducted oceanic crust, various kinds of subducted sediment, detached subcontinental lithosphere, recycled continental crust, metasomatized mantle, oceanic lithosphere, primordial mantle, or upper mantle peridotite, pyroxenite, or eclogite (e.g., Lupton and Craig, 1975; Zindler and Hart, 1986; Menzies and Hawkesworth, 1987; Hart, 1988; McDonough, 1991; Plank and Langmuir, 1998; Class and le Roex, 2006, 2008; Jackson et al., 2007).

These OIB geochemical complexities are enhanced when we consider the volcanic evolution of a single seamount, an oceanic island, or an entire seamount trail. Each seamount and oceanic island goes through a series of evolutionary volcanic stages (see Staudigel and Clague, 2010). In most cases, construction seems to be completed in less than 1-2 million years, yet in some other cases, the buildup may be longer, up to 12 million years, for example, at Tenerife. At Hawai $i$, up to $98 \%$ of the volcanic output is produced in the so-called "shield stage" that builds up the bulk of the volcano structure in just a couple of hundred thousand years, with primarily tholeiitic basalts (e.g., Clague et al., 1989). If this stage is sufficiently voluminous and eruption rates are high enough, seamounts may evolve into islands before volcanism dies down and transitions into a short post-shield "capping stage" of alkali basalt volcanism. Erosion now becomes prevalent, and after a prolonged period of volcanic quiescence, a rather small volume of highly differentiated basalts may erupt in the so-called "post-erosional" stage (e.g., the Honolulu Volcanic Series). In
Figure 8. Based on a combination of geochemical and geophysical observations, different mantle convection and "Earth structure" models have entered the literature since the early 1970s. First, it was shown that the mantle source materials for MORB and OIB basalts were different based on the earliest ${ }^{87} \mathrm{Sr} /{ }^{86} \mathrm{Sr}$ isotope measurements (Hart, 1971; Hart et al., 1973). To explain this difference, Schilling (1973a, 1973b) brought in the concept of mantle plumes originating in the lower mantle. Using new ${ }^{143} \mathrm{Nd} /{ }^{144} \mathrm{Nd}$ isotope evidence, Wasserburg, DePaolo, and Jacobsen (Jacobsen and Wasserburg, 1979; Wasserburg and Depaolo, 1979) then argued that part of the mantle may be (more) "primitive" and from this proposed the two-layered mantle model. However, Zindler et al. (1982) demonstrated that the mantle must contain at least three components, setting the stage for more complex mantle models later on. Various versions of "marble-cake," "two-stage," and "deep-layer" whole-mantle convection models have by now been proposed (e.g., Zindler et al., 1984; Allègre and Turcotte, 1986; Kellogg et al., 1999; Phipps Morgan and Morgan, 1999), often combining both geochemical and geophysical evidence, such as seismological data providing tomographic evidence for the penetration of subducting slabs into the lower mantle (e.g., Van der Hilst et al., 1997).

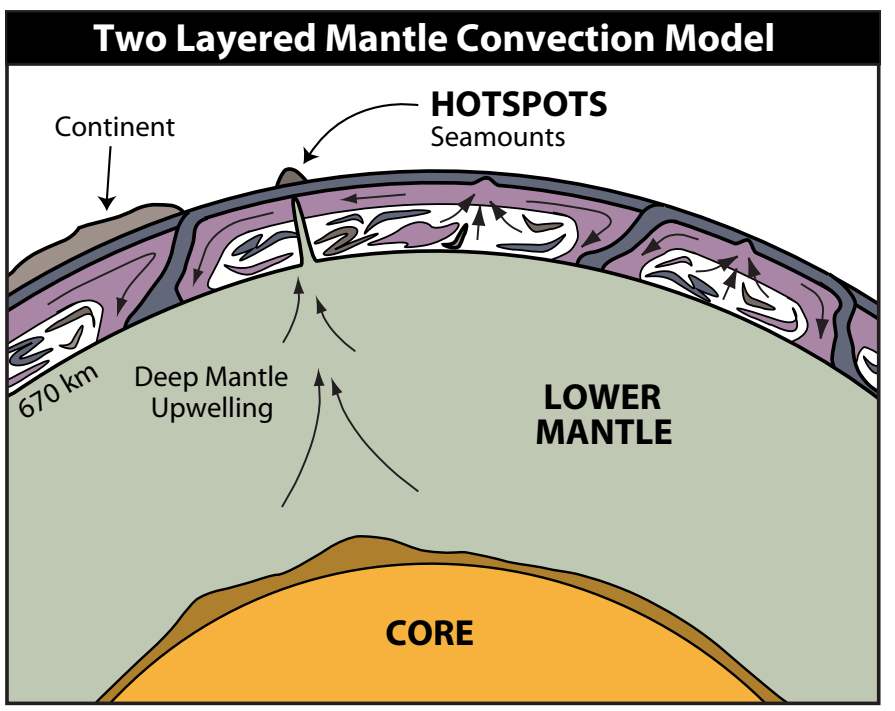


some cases, and following a longer period of volcanic inactivity, volcanism may reoccur, typically when plate tectonic motions reposition a seamount over another independent source of intraplate volcanism, allowing for the "rejuvenated" volcanic stage. Each of the above stages are characterized by a different suite of rock types and variations in their mantle source geochemistry, most likely rooted in the way mantle plumes interact with oceanic lithosphere, how the thermalchemical character and depth of the melting zones change over time, and how the present mantle sources are sampled in different ways by the magmatic processes (e.g., Duncan et al., 1986; Regelous et al., 2003; Keller et al., 2004; Ren et al., 2005). As a result, some hotspot trails (e.g., Samoa, Louisville) produce alkalic shield lavas where the Hawaiian hotspot produces tholeiites, don't show evidence for widespread post-erosional volcanism, and have late-stage volcanism only slightly different from the basalts formed during the earlier shield stage.

A related issue that remains to be discussed is the persistence or longevity of mantle components in a vigorously convecting mantle (Staudigel et al., 1991; Koppers et al., 2003), which is directly coupled to the development, dispersal, and destruction of thermo-chemical mantle upwellings (Farnetani and Samuel, 2005; Lin and van Keken, 2006a; Davies and Davies, 2009). Because the OIB source sampled changes readily during the buildup of a single seamount or oceanic island, and because it also changes from one volcanic feature to another in a seamount trail, it is hard to provide solid evidence on the longevity of mantle domains that have a single dominant mantle component (e.g., depleted MORB mantle [DMM], high U/Pb mantle [HIMU]; see Figure 7). However, it is starting to become clear now that, on large length scales (up to a couple of hundred kilometers), mantle sources are consistently present over at least tens or even hundreds of millions of years (Konter et al., 2008). Although the Hawaiian hotspot has been sampling only a relatively small mantle region a few hundred kilometers in diameter (Wolfe et al., 2009), it has been producing shield lavas of more or less similar isotopic geochemistry for more than 80 million years (Keller et al., 2004). Another good example is the Dupal mantle anomaly that spans the entire globe in a large band south of the equator (Hart, 1984) and that is isotopically unique in exhibiting high ${ }^{207} \mathrm{~Pb} /{ }^{204} \mathrm{~Pb}$ and ${ }^{208} \mathrm{~Pb} /{ }^{204} \mathrm{~Pb}$ isotope ratios at a given ${ }^{206} \mathrm{~Pb} /{ }^{204} \mathrm{~Pb}$ ratio when compared to OIB found in the Northern Hemisphere. Its origin remains an enigma, yet it is thought that early on in Earth's history, some of the lower continental crust was "stranded" in the lower mantle, where it has remained ever since to form the largest isotopic mantle anomaly observed both today (Castillo, 1988) and far back into geological time (Staudigel et al., 1991; Peate et al., 1999).

However, not all seamounts have OIB characteristics and are plume-related. The largest number of seamounts were formed near mid-ocean spreading centers and carry slightly enriched
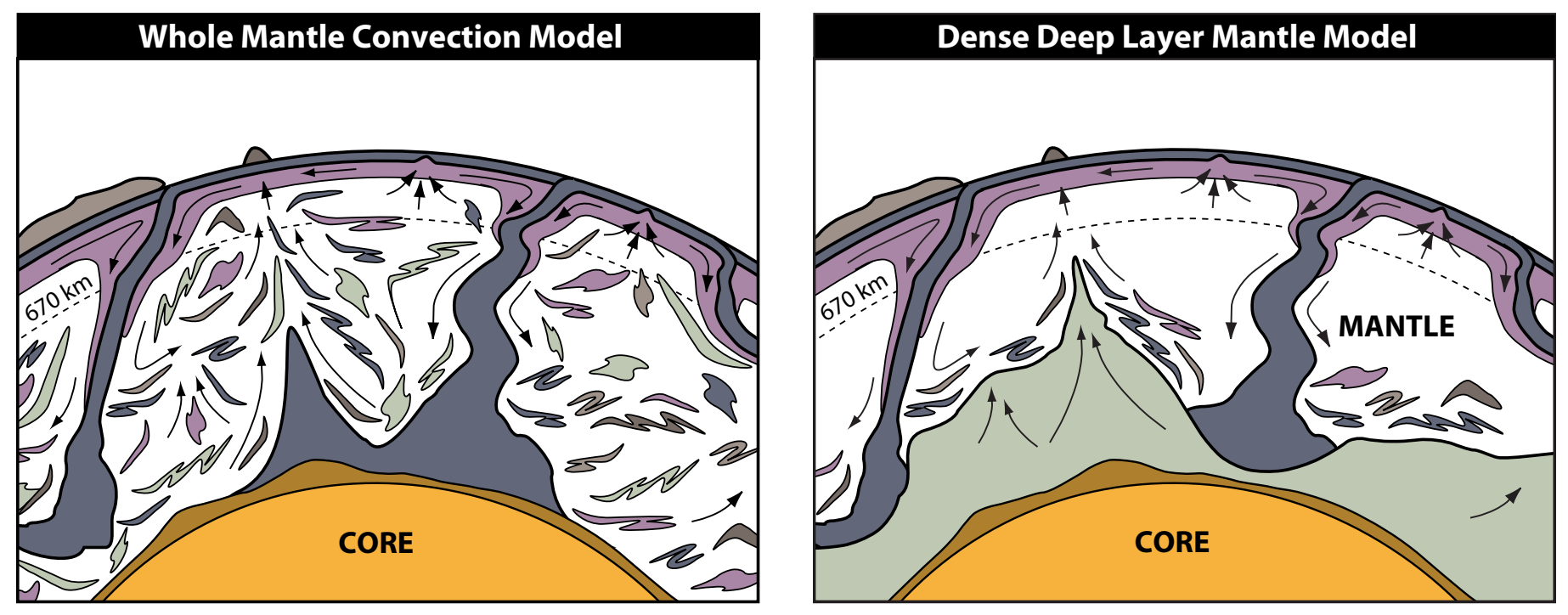
MORB-like signatures (Batiza and Vanko, 1984; Zindler et al., 1984; Batiza et al., 1990). These near-ridge seamounts are abundant and small in volume and size (Batiza, 1982), but they are different geochemically from normal MORB (or, N-MORB; Zindler et al., 1984) and thus indicative of the heterogeneous character of the upper mantle. It is unknown how many of the world's $\sim 200,000$ seamounts fall into this category, but based on flexure modeling (Figure 6), at least $60 \%$ of the seamounts studied were found to have been emplaced in an "on-ridge" setting.

Another group of seamounts were formed as part of the island arcs located on the overriding plates of ocean-ocean subduction zones. Here, the number of seamounts are limited, yet geochemical studies of these seamounts have been important in determining which elements are preferentially stripped from the subducting oceanic plates (and the sediment/seamounts on top) in what has been dubbed the "subduction zone factory" (e.g., Stern, 2002; Kelley et al., 2005; Tollstrup and Gill, 2005). This factory effectively acts as a geochemical filter and determines which kind and what amount of material is being recycled into Earth's mantle, where it becomes available as enriched mantle sources (e.g., HIMU, Enriched Mantle 1 and 2 [EMI and EMII] in Figure 7) for intraplate OIB seamounts again (see Staudigel et al., 2010).

Finally, seamount petrology and geochemistry can be used to probe the potential temperatures of the mantle sources. In the case of intraplate seamounts and oceanic islands, petrology and geochemistry provide estimates of the temperature anomalies associated with hotspots and mantle plumes (Herzberg et al., 2007; Putirka, 2008). When compared to the mean $1350 \pm 50^{\circ} \mathrm{C}$ temperature (Courtier et al., 2007) of an upper mantle MORB source, many hotspots are modeled to have increased temperatures 100 to $300^{\circ} \mathrm{C}$ (Putirka, 2008) or $150 \pm 100^{\circ} \mathrm{C}$ (Courtier et al., 2007) higher. However, other researchers claim that these excess temperatures are not necessary and that some seamount trails are rather evidence for "damp," "wet," and "cold” spots, whereby increased volatile content $\left(\mathrm{H}_{2} \mathrm{O}, \mathrm{CO}_{2}\right)$ in the mantle sources also produces enriched OIB volcanoes following only a small degree of partial melting from shallow mantle sources (e.g., Anderson, 2000; Foulger and Natland, 2003; Finn et al., 2005).

\section{FRONTIERS}

Many first-order physical and chemical applications in the general field of geodynamics remain areas of active research with important questions to be answered. In this group of questions, the role of intraplate seamounts is pivotal in increasing our overall understanding of the deep geodynamical Earth. For example, can a single model, like a hotspot fed by a long-lived and stationary mantle plume, explain intraplate volcanism? Do hotspots move, and where in the mantle do mantle plumes originate? What does this mean for mantle convection? Are seamount trails tracing the tail or stem of a mantle plume after their plume heads have reached Earth's surface and produced a large igneous province? Can we use the geochemical history of seamount trails to better understand mantle melting and the causes for mantle geochemical heterogeneity? When seamounts subduct, do they contribute significantly to the geochemistry of the subduction zone factory?

Much less than $1 \%$ of the roughly 47,000 seamounts taller than $500 \mathrm{~m}$ in the world ocean has been categorically mapped, sampled, or analyzed. Before we can start to answer the multitude of questions, we will have to collect a vast amount more geochemical and geophysical data. This challenge leaves the ocean wide open for future seamount exploration.

\section{ACKNOWLEDGEMENTS}

AAPK was supported by the National Science Foundation through the SBN Research Coordination Network (EF-0443337). We would like to thank Stan Hart for an insightful and detailed review of our manuscript. ⿷匚

\section{REFERENCES}

Albarede, F., and R.D. van der Hilst. 2002. Zoned mantle convection. Philosophical Transactions of the Royal Society of London A 360:2,569-2,592.

Ali, M.Y., A.B. Watts, and I. Hill. 2003. A seismic reflection profile study of lithospheric flexure in the vicinity of the Cape Verde Islands. Journal of Geophysical Research 108(B5), 2239, doi:10.1029/2002JB002155.

Allègre, C.J. 1982. Chemical geodynamics. Tectonophysics 81:109-132.

Allègre, C.J., and D.L. Turcotte. 1986. Implications of a two-component marble-cake mantle. Nature 323:123-127.

Anderson, D.L. 2000. The thermal state of the upper mantle: No role for mantle plumes. Geophysical Research Letters 27(22):3,623-3,626.

Batiza, R. 1982. Abundances, distribution and sizes of volcanoes in the Pacific Ocean and implications for the origin of non-hotspot volcanoes. Earth and Planetary Science Letters 60:195-206.

Batiza, R., Y. Niu, and W.C. Zayac. 1990. Chemistry of seamounts near the East Pacific Rise: Implications for the geometry of subaxial mantle flow. Geology 18:1,122-1,125.

Batiza, R., and D. Vanko. 1984. Petrology of young Pacific seamounts. Journal of Geophysical Research 89:11,235-11,260. 
Boyet, M., and R.W. Carlson. 2006. A new geochem ical model for the Earth's mantle inferred from (SM)-S-146-Nd-142 systematics. Earth and Planetary Science Letters 250(1-2):254-268.

Canales, J.P., J.J. Dañobeitia, and A.B. Watts. 2000. Wide-angle seismic constraints on the internal structure of Tenerife, Canary Islands. Journal of Volcanology and Geothermal Research 103(1-4):65-81.

Cande, S.C., C.A. Raymond, J. Stock, and W.F. Haxby. 1995. Geophysics of the Pitman Fracture Zone and Pacific-Antarctic Plate Motions during the Cenozoic. Science 270(5238):947-953.

Caress, D.W., M.K. McNutt, R.S. Detrick, and J.C. Mutter. 1995. Seismic imaging of hotspotrelated crustal underplating beneath the Marquesas Islands. Nature 373(6515):600-603.

Castillo, P. 1988. The Dupal anomaly as a trace of the upwelling lower mantle. Nature 336:667-670.

Charvis, P., A. Laesanpura, J. Gallart, A. Hirn, J.C. Lepine, B. de Voogd, T.A. Minshull, Y. Hello, and B. Pontoise. 1999. Spatial distribution of hotspot material added to the lithosphere under La Reunion, from wideangle seismic data. Journal of Geophysical Research 104(B2):2,875-2,893.

E. Contreras-Reyes, I. Grevemeyer, A.B. Watts, L. Planert, E.R. Flueh, and C. Peirce. Crustal intrusion beneath the Louisville hotspot track. Earth and Planetary Science Letters 289(2010):323-333, doi:10.1016/ j.epsl.2009.11.020.

Clague, D.A., and G.B. Dalrymple. 1987. The Hawaiian-Emperor volcanic chain: Part I. Geologic evolution. Pp. 5-54 in Volcanism in Hawaii. R.W. Decker, T.L. Wright, and P.H. Stauffer, eds, US Geological Survey Professional Paper 1350.

Clague, D.A., G.B. Dalrymple, T.L. Wright, F.W. Klein, R.Y. Koyanagi, R.W. Decker, and D.M. Thomas. 1989. The Hawaiian-Emperor chain. Pp. 187-287 in The Geology of North America: The Eastern Pacific Ocean and Hawaii. E.L. Winterer, D.M. Hussong, and R.W. Decker, eds, Geological Society of America, Boulder, CO.

Class, C., and A.P. le Roex. 2006. Continental material in the shallow oceanic mantle: How does it get there? Geology 34(3):129-132.

Class, C., and A.P. le Roex. 2008. Ce anomalies in Gough Island lavas: Trace element characteristics of a recycled sediment component. Earth and Planetary Science Letters 265(3-4):475-486.

Clouard, V., and M. Gerbault. 2008. Break-up spots: Could the Pacific open as a consequence of plate kinematics? Earth and Planetary Science Letters 265(1-2):195-208.

Courtier, A.M., M.G. Jackson, J.F. Lawrence, Z. Wang, C.T.A. Lee, R. Halama, J.M. Warren, R. Workman, W. Xu, M.M. Hirschmann, and others. 2007. Correlation of seismic and petrologic thermometers suggests deep thermal anomalies beneath hotspots. Earth and Planetary Science Letters 264(1-2):308-316.
Courtillot, V., A. Davaille, J. Besse, and J. Stock. 2003. Three distinct types of hotspots in the Earth's mantle. Earth and Planetary Science Letters 205(3-4):295-308, doi:10.1016/S0012$821 \mathrm{X}(02) 01048-8$.

Courtney, R.C., and R.S. White. 1986. Anomalous heat-flow and geoid across the Cape-Verde Rise: Evidence for dynamic support from a thermal plume in the mantle. Geophysical Journal of the Royal Astronomical Society 87(3):815-867.

Davaille, A., and J. Vatteville. 2005. On the transient nature of mantle plumes. Geophysical Research Letters 32, L14309, doi:10.1029/2005GL023029.

Davies, D.R., and J.H. Davies. 2009. Thermallydriven mantle plumes reconcile multiple hotspot observations. Earth and Planetary Science Letters 278(1-2):50-54.

Davies, G.F. 1988. Ocean bathymetry and mantle convection: 1. Large-scale flow and hotspots. Journal of Geophysical Research 93(B9):10,467-10,480.

Davis, A.S., L.B. Gray, D.A. Clague, and J.R. Hein. 2002. The Line Islands revisited: $\mathrm{New}{ }^{40} \mathrm{Ar} /{ }^{39} \mathrm{Ar}$ geochronologic evidence for episodes of volcanism due to lithospheric extension. Geochemistry Geophysics Geosystems 3, doi:10.1029/2001GC000190.

Detrick, R.S., R.P. Von Herzen, B. Parsons, D. Sandwell, and M. Dougherty. 1986. Heat-flow observations on the Bermuda Rise and thermal models of midplate swells. Journal of Geophysical Research 91(B3):3,701-3,723.

Duncan, R.A., and R.A. Keller. 2004. Radiometric ages for basement rocks from the Emperor Seamounts, ODP Leg 197. Geochemistry, Geophysics, Geosystems 5, Q08L03, doi:10.1029/ 2004GC000704

Duncan, R.A., M.T. McCulloch, H.G. Barsczus, and D.R. Nelson. 1986. Plume versus lithospheric sources for melts at Ua Pou, Marquesas Islands. Nature 322(6079):534-538.

Duncan, R.A., J.A. Tarduno, and D.W. Scholl. 2006. Leg 197 Synthesis: Southward motion and geochemical variability of the Hawaiian Hotspot. In: Proceedings of the Ocean Drilling Program, Scientific Results. R.A. Duncan, J.A. Tarduno, T.A. Davies and D.W. Scholl, eds. Available online at: http://www-odp.tamu.edu/ publications/197_SR/synth/synth.htm (accessed December 15, 2009).

Farnetani, C.G., and H. Samuel. 2003. Lagrangian structures and stirring in the Earth's mantle. Earth and Planetary Science Letters 206(3-4):335-348.

Farnetani, C.G., and H. Samuel. 2005. Beyond the thermal plume paradigm. Geophysical Research Letters 32, L07311, doi:10.1029/2005GL022360.

Finn, C.A., R.D. Müller, and K.S. Panter. 2005. A Cenozoic diffuse alkaline magmatic province (DAMP) in the southwest Pacific without rift or plume origin. Geochemistry, Geophysics, Geosystems 6, Q02005, doi:10.1029/ 2004GC000723.
Fisher, A.T., and C.G. Wheat. 2010. Seamounts as conduits for massive fluid, heat, and solute fluxes on ridge flanks. Oceanography 23(1):74-87.

Forsyth, D.W., N. Harmon, D.S. Scheirer, and R.A. Duncan. 2006. Distribution of recent volcanism and the morphology of seamounts and ridges in the GLIMPSE study area: Implications for the lithospheric cracking hypothesis for the origin of intraplate, non-hot spot volcanic chains. Journal of Geophysical Research 111, B11407, doi:10.1029/2005JB004075.

Foulger, G.R., and J.H. Natland. 2003. Is "hotspot" volcanism a consequence of plate tectonics? Science 300(5621):921-922, doi:10.1126/ science.1083376.

Galer, S.J.G., and R.K. O'Nions. 1985. Residence time of thorium, uranium and lead in the mantle with implications for mantle convection. Nature 316:778-782.

Goodwillie, A.M. 1995. Short-wavelength gravity lineations and unusual flexure results at the Puka Puka volcanic ridge system. Earth and Planetary Science Letters 136(3-4):297-314.

Griffiths, R.W., and I.H. Campbell. 1991. On the dynamics of long-lived plume conduits in the convecting mantle. Earth and Planetary Science Letters 103:214-227.

Harris, R.N., and M.K. McNutt. 2007. Heat flow on hot spot swells: Evidence for fluid flow. Journal of Geophysical Research B: Solid Earth 112, B03407, doi:10.1029/2006JB004299.

Hart, S.R. 1971. K, Rb, Cs, Sr and Ba contents and Sr isotope ratios of ocean floor basalts. Philosophical Transactions of the Royal Society of London A 268(1192):573-587, doi:10.1098/rsta.1971.0013.

Hart, S.R. 1984. A large scale isotope anomaly in the Southern Hemisphere mantle. Nature 309:753-757.

Hart, S.R. 1988. Heterogeneous mantle domains: Signatures, genesis and mixing chronologies. Earth and Planetary Science Letters 90:273-296.

Hart, S.R., E.H. Hauri, L.A. Oschmann, and J.A. Whitehead. 1992. Mantle plumes and entrainment: Isotopic evidence. Science 256(5056):517-520.

Hart, S.R., J.-G. Schilling, and J.L. Powell. 1973. Basalts from Iceland and along Reykjanes Ridge: Sr isotope geochemistry. Nature 246(155):104-107.

Hawkesworth, C.J., and A.I.S. Kemp. 2006. Evolution of the continental crust. Nature 443(7113):811-817.

Hawkesworth, C.J., N.W. Rogers, P.W.C. van Calsteren, and M.A. Menzies. 1984. Mantle enrichment processes. Nature 311:331-335.

Herzberg, C., P.D. Asimow, N. Arndt, Y.L. Niu, C.M. Lesher, J.G. Fitton, M.J. Cheadle, and A.D. Saunders. 2007. Temperatures in ambient mantle and plumes: Constraints from basalts, picrites, and komatiites. Geochemistry, Geophysics, Geosystems 8, Q02006, doi:10.1029/2006GC001390. 
Hess, H.H. 1946. Drowned ancient islands of the Pacific basin. American Journal of Science 244:772-791.

Hillier, J.K. 2007. Pacific seamount volcanism in space and time. Geophysical Journal International 168(2):877-889.

Hillier, J.K., and A.B. Watts. 2007. Global distribution of seamounts from ship-track bathymetry data. Geophysical Research Letters 34, L13304, doi:10.1029/2007GL029874.

Hofmann, A.W. 2003. Sampling mantle heterogeneity through oceanic basalts: Isotopes and trace elements. Pp. 61-101 in The Mantle and Core. R.W. Carlson, ed., Treatise on Geochemistry, vol. 2, Elsevier-Pergamon, Oxford.

Hofmann, A.W., and W.M. White. 1982. Mantle plumes from ancient oceanic crust. Earth and Planetary Science Letters 57:421-436.

Jackson, E.D., E.A. Silver, and G.B. Dalrymple. 1972. Hawaiian-Emperor chain and its relation to Cenozoic circumpacific tectonics. Geological Society of America Bulletin 83:601-618.

Jackson, M.G., S.R. Hart, A.A.P. Koppers, H. Staudigel, J. Konter, J. Blusztajn, M.D. Kurz, and J.A. Russell. 2007. The return of subducted continental crust in Samoan lavas. Nature 448:684-687, doi:10.1038/nature06048.

Jacobsen, S.B., and G.J. Wasserburg. 1979. Mean age of mantle and crustal reservoirs. Journal of Geophysical Research 84:7,411-7,427.

Keller, R.A., D.W. Graham, K.A. Farley, R.A. Duncan, and J.E. Lupton. 2004. Cretaceous-torecent record of elevated ${ }^{3} \mathrm{He} /{ }^{4} \mathrm{He}$ along the Hawaiian-Emperor volcanic chain. Geochemistry, Geophysics, Geosystems 5, Q12L05, doi:10.1029/2004GC000739.

Kelley, K.A., T. Plank, L. Farr, J. Ludden, and H. Staudigel. 2005. Subduction cycling of $\mathrm{U}$, Th and $\mathrm{Pb}$. Earth and Planetary Science Letters 234(3-4):369-383.

Kellogg, L.H., B.H. Hager, and D. van der Hilst. 1999. Compositional stratification in the deep mantle. Science 283:1,881-1,884.

Konter, J.G., B.B. Hanan, J. Blichert-Toft, A.P.P. Koppers, T. Plank, and H. Staudigel. 2008. One hundred million years of mantle geochemical history suggest the retiring of mantle plumes is premature. Earth and Planetary Science Letters 275(3-4):285-295.

Koppers, A.A.P., and H. Staudigel. 2005. Asynchronous bends in Pacific seamount trails: A case for extensional volcanism? Science 307:904-907, doi:10.1126/science.1107260.

Koppers, A.A.P., R.A. Duncan, and B. Steinberger. 2004. Implications of a non-linear ${ }^{40} \mathrm{Ar} /{ }^{39} \mathrm{Ar}$ age progression along the Louisville seamount trail for models of fixed and moving hotspots. Geochemistry, Geophysics, Geosystems 5(6), Q06L02, doi:10.1029/2003GC000671.

Koppers, A.A.P., J.P. Morgan, J.W. Morgan, and H. Staudigel. 2001. Testing the fixed hotspot hypothesis using ${ }^{40} \mathrm{Ar} /{ }^{39} \mathrm{Ar}$ age progressions along seamount trails. Earth and Planetary Science Letters 185(3-4):237-252.
Koppers, A.A.P., J.A. Russell, M. Jackson, J. Konter, H. Staudigel, and S.R. Hart. 2008. Samoa reinstated as a primary hotspot trail. Geology 36(6):435-438, doi:10.1130/G24630A.1.

Koppers, A.A.P., H. Staudigel, J. Phipps Morgan, and R.A. Duncan. 2007. Non-linear ${ }^{40} \mathrm{Ar} /{ }^{39} \mathrm{Ar}$ age systematics along the Gilbert Ridge and Tokelau Seamount Trail and the timing of the Hawaii-Emperor Bend. Geochemistry, Geophysics, Geosystems, 8, Q06L13, doi:10.1029/2006GC001489.

Koppers, A.A.P., H. Staudigel, M.S. Pringle, and J.R. Wijbrans. 2003. Short-lived and discontinuous intraplate volcanism in the South Pacific: Hot spots or extensional volcanism? Geochemistry, Geophysics, Geosystems 4(10), 1089, doi:10.1029/2003GC000533.

Koppers, A.A.P., H. Staudigel, J.R. Wijbrans, and M.S. Pringle. 1998. The Magellan seamount trail: Implications for Cretaceous hotspot volcanism and absolute Pacific Plate motion. Earth and Planetary Science Letters 163(1-4):53-68.

Lin, S.C., and P.E. van Keken. 2006a. Deformation, stirring and material transport in thermochemical plumes. Geophysical Research Letters 33, L20306, doi:10.1029/2006GL027037.

Lin, S.C., and P.E. van Keken. 2006b. Dynamics of thermochemical plumes: 2. Complexity of plume structures and its implications for mapping mantle plumes. Geochemistry, Geophysics, Geosystems 7, Q03003, doi:10.1029/2005GC001072.

Lindle, M.E., L.E. Colwell, A.A.P. Koppers, and R.A. Duncan. 2008. Evidence for differential Hawaiian and Louisville plume motions based on ${ }^{40} \mathrm{Ar} /{ }^{39} \mathrm{Ar}$ geochronology. Eos, Transactions, American Geophysical Union, Fall Meeting 89(53):IN41A-1121.

Lupton, J.E., and H. Craig. 1975. Excess ${ }^{3} \mathrm{He}$ in oceanic basalts: Evidence for terrestrial primordial helium. Earth and Planetary Science Letters 26:133-139.

McDonough, W.F. 1991. Partial melting of subducted oceanic crust and isolation of its residual eclogitic lithology. Philosophical Transactions of the Royal Society of London A 335:407-418.

McDougall, I., and R.A. Duncan. 1980. Linear volcanic chains: Recording plate motions? Tectonophysics 63:275-295.

McKenzie, D., and R.K. O’Nions. 1983. Mantle reservoirs and ocean island basalts. Nature 301:229-231.

McKenzie, D.P., and W.J. Morgan. 1969. Evolution of triple junctions. Nature 224(5215):125-133.

McKenzie, D.P., and R.L. Parker. 1967. The North Pacific: An example of tectonics on a sphere. Nature 216(5122):1,276-1,280.

McNutt, M.K. 1984. Lithospheric flexure and thermal anomalies. Journal of Geophysical Research 89:11,180-11,194.

McNutt, M.K. 1998. Superswells. Reviews of Geophysics 36(2):211-244.
Menzies, M.A., and C.J. Hawkesworth, eds. 1987. Mantle Metasomatism. Academic Press, London, 472 pp.

Montelli, R., G. Nolet, F.A. Dahlen, and G. Masters. 2006. A catalogue of deep mantle plumes: New results from finite-frequency tomography. Geochemistry, Geophysics, Geosystems 7, Q11007, doi:10.1029/2006GC001248.

Morgan, W.J. 1968. Rises, trenches, great faults, and crustal blocks. Journal of Geophysical Research 73(6):1,959-1,982.

Morgan, W.J. 1971. Convection plumes in the lower mantle. Nature 230(5288):42-43.

Morgan, W.J. 1972. Plate motions and deep mantle convection. Geological Society of America, Memoir 132 (Hess Volume), 7-22.

Muller, R.D., J.Y. Royer, and L.A. Lawver. 1993. Revised plate motions relative to the hotspots from combined Atlantic and Indian Ocean hotspot tracks. Geology 21(3):275-278.

Nataf, H.C. 2000. Seismic imaging of mantle plumes. Annual Review of Earth and Planetary Sciences 28:391-417.

Natland, J., and E.L. Winterer. 2005. Fissure control on volcanic action in the Pacific. Pp. 687-710 in Plumes, Plates and Paradigms. G.R. Foulger, J. Natland, D. Presnall, and D.L. Anderson, eds, Geological Society of America, Boulder, CO.

O'Connor, J.M., P. Stoffers, J.R. Wijbrans, and T.J. Worthington. 2007. Migration of widespread long-lived volcanism across the Galápagos Volcanic Province: Evidence for a broad hotspot melting anomaly? Earth and Planetary Science Letters 263(3-4):339-354, doi:10.1016/ j.epsl.2007.09.007.

Peate, D.W., C.J. Hawkesworth, M.M.S. Mantovani, N.W. Rogers, and S.P. Turner. 1999. Petrogenesis and stratigraphy of the high-Ti/Y Urubici magma type in the Parana Flood Basalt Province and implications for the nature of 'Dupal'-type mantle in the South Atlantic Region. Journal of Petrology 40(3):451-473.

Peirce, C., and P.J. Barton. 1991. Crustal structure of the Madeira-Tore Rise, eastern North Atlantic: Results of a DOBS wide-angle and normal incidence seismic experiment in the Josephine Seamount region. Geophysical Journal International 106(2):357-378.

Phipps Morgan, J., and W.J. Morgan. 1999. Two-stage melting and the geochemical evolution of the mantle: A recipe for mantle plum-pudding. Earth and Planetary Science Letters 170(3):215-239.

Pim, J., C. Peirce, A.B. Watts, I. Grevemeyer, and A. Krabbenhoeft. 2008. Crustal structure and origin of the Cape Verde Rise. Earth and Planetary Science Letters 272(1-2):422-428.

Plank, T., and C.H. Langmuir. 1998. The geochemical composition of subducting sediment and its consequences for the crust and mantle. Chemical Geology 145:325-394.

Putirka, K. 2008. Excess temperatures at ocean islands: Implications for mantle layering and convection. Geology 36(4):283-286. 
Regelous, M., A.W. Hofmann, W. Abouchami, and S.J.G Galer. 2003. Geochemistry of lavas from the Emperor Seamounts, and the geochemical evolution of Hawaiian magmatism from 85 to $42 \mathrm{Ma}$. Journal of Petrology 44(1):113-140.

Ren, Z.Y., S. Ingle, E. Takahashi, N. Hirano, and T. Hirata. 2005. The chemical structure of the Hawaiian mantle plume. Nature 436(7052):837-840.

Richards, M.A., R.A. Duncan, and V.E. Courtillot. 1989. Flood basalts and hot-spot tracks: Plume heads and tails. Science 246(4926):103-107.

Sandwell, D., and Y. Fialko. 2004. Warping and cracking of the Pacific Plate by thermal contraction. Journal of Geophysical Research 109, B10411, doi:10.1029/2004JB003091.

Sandwell, D.T., E.L. Winterer, J. Mammerickx, R.A. Duncan, M.A. Lynch, D.A. Levitt, and C.L. Johnson. 1995. Evidence for diffuse extension of the Pacific Plate from Pukapuka Ridges and cross-grain gravity lineations. Journal of Geophysical Research 100(B8):15,087-15,099.

Schilling, J.-G. 1973a. Afar mantle plume: Rare earth evidence. Nature. Physical Science 242:2-6.

Schilling, J.-G. 1973b. Iceland mantle plume: Geochemical evidence along Reykjanes ridge. Nature 242:565-571.

Sharp, W.D., and D.A. Clague. 2006. 50-Ma initiation of Hawaiian-Emperor bend records major change in Pacific Plate motion. Science 313(5791):1,281-1,284.

Sheehan, A.F., and M.K. McNutt. 1989. Constraints on thermal and mechanical structure of the oceanic lithosphere at the Bermuda Rise from geoid height and depth anomalies. Earth and Planetary Science Letters 93(3-4):377-391.

Sleep, N.H. 1990. Hotspots and mantle plumes: Some phenomenology. Journal of Geophysical Research 95:6,715-6,736.

Staudigel, H., and D.A. Clague. 2010. The geological history of deep-sea volcanoes: Biosphere, hydrosphere, and lithosphere interactions. Oceanography 23(1):58-71.

Staudigel, H., A.A.P. Koppers, T.A. Plank, and B.B. Hanan. 2010. Seamounts in the subduction factory. Oceanography 23(1):176-181.

Staudigel, H., K.-H. Park, M. Pringle, J.L. Rubenstone, W.H.F. Smith, and A. Zindler. 1991. The longevity of the South Pacific isotope and thermal anomaly. Earth and Planetary Science Letters 102:24-44.

Steinberger, B. 2000. Plumes in a convecting mantle: Models and observations for individual hotspots. Journal of Geophysical Research 105(B5):11,127-11,152.

Steinberger, B., and M. Antretter. 2006. Conduit diameter and buoyant rising speed of mantle plumes: Implications for the motion of hot spots and shape of plume conduits. Geochemistry, Geophysics, Geosystems 7, Q11018, doi:10.1029/2006GC001409.
Steinberger, B., and R.J. O'Connell. 1998. Advection of plumes in mantle flow: Implications for hotspot motion, mantle viscosity and plume distribution. Geophysical Journal International 132(2):412-434.

Steinberger, B., R. Sutherland, and R.J. O'Connell. 2004. Prediction of Emperor-Hawaii seamount locations from a revised model of global plate motion and mantle flow. Nature 430(6996):167-173.

Stern, R.J. 2002. Subduction zones. Reviews of Geophysics 40, 1012, doi:10.1029/2001RG000108.

Tarduno, J., H.-P. Bunge, N. Sleep, and U. Hansen. 2009. The bent Hawaiian-Emperor hotspot track: Inheriting the mantle wind. Science 324(5923):50-53, doi:10.1126/science.1161256.

Tarduno, J.A., R.A. Duncan, D.W. Scholl, R.D. Cottrell, B. Steinberger, T. Thordarson, B.C. Kerr, C.R. Neal, F.A. Frey, M. Torii, and C. Carvallo. 2003. The Emperor Seamounts: Southward motion of the Hawaiian hotspot plume in Earth's mantle. Science 301(5636):1,064-1,069, doi:ç10.1126/ science.1086442.

Tollstrup, D.L., and J.B. Gill. 2005. Hafnium systematics of the Mariana arc: Evidence for sediment melt and residual phases. Geology 33(9):737-740.

Van der Hilst, R.D., S. Widiyantoro, and R.L. Engdahl. 1997. Evidence for deep mantle circulation from global tomography. Nature 386:578-584.

Van Keken, P. 1997. Evolution of starting mantle plumes: A comparison between numerical and laboratory models. Earth and Planetary Science Letters 148(1-2):1-11.

Von Herzen, R.P., R.S. Detrick, S.T. Crough, D. Epp, and U. Fehn. 1982. Thermal origin of the Hawaiian swell: Heat-flow evidence and thermal models. Journal of Geophysical Research 87(B8):6,711-6,723.

Wasserburg, G.J., and D.J. Depaolo. 1979. Models of Earth structure inferred from neodymium and strontium isotopic abundances. Proceedings of the National Academy of Sciences of the United States of America 76(8):3,594-3,598.

Watts, A.B. 1976. Gravity and bathymetry in the Central Pacific Ocean. Journal of Geophysical Research 81:1,533-1,553.

Watts, A.B. 2001. Isostasy and Flexure of the Lithosphere. Cambridge University Press, 458 pp.

Watts, A.B., and U.S. ten Brink. 1989. Crustal structure, flexure and subsidence history of the Hawaiian Islands. Journal of Geophysical Research 94:10,743-10,500.

Watts, A.B., and S. Zhong. 2000. Observations of flexure and the rheology of oceanic lithosphere. Geophysical Journal International 142:855-875.

Watts, A.B., C. Peirce, J. Collier, R. Dalwood, J.P. Canales, and T.J. Henstock. 1997. A seismic study of lithospheric flexure in the vicinity of Tenerife, Canary Islands. Earth and Planetary Science Letters 146(3-4):431-447.
Watts, A.B., D.T. Sandwell, W.H.F. Smith, and P. Wessel. 2006. Global gravity, bathymetry, and the distribution of submarine volcanism through space and time. Journal of Geophysical Research 111, B08408, doi:10.1029/2005JB004083.

Watts, A.B., U.S. ten Brink, P. Buhl, and T. Brocher. 1985. A multichannel seismic study of lithospheric flexure across the Hawaiian-Emperor seamount chain. Nature 315:105-111.

Watts, A.B., J.K. Weissel, R.A. Duncan, and R.L. Larson. 1988. Origin of the Louisville Ridge and its relationship to the Eltanin fracture zone system. Journal of Geophysical Research 93:3,051-3,077.

Weigel, W., and I. Grevemeyer. 1999. The Great Meteor seamount: Seismic structure of a submerged intraplate volcano. Journal of Geodynamics 28(1):27-40.

Wessel, P., and L.W. Kroenke. 2008. Pacific absolute plate motion since $145 \mathrm{Ma}$ : An assessment of the fixed hot spot hypothesis. Journal of Geophysical Research 113, B06101, doi:10.1029/2007JB005499.

Wessel, P., D.T. Sandwell, and S.-S. Kim. 2010. The global seamount census. Oceanography 23(1):24-33.

White, W.M., J.G. Schilling, and S.R. Hart. 1976. Evidence for the Azores mantle plume from strontium isotope geochemistry of the Central North-Atlantic. Nature 263(5579):659-663, doi:10.1038/263659a0.

Wilson, J.T. 1963. A possible origin of the Hawaiian Islands. Canadian Journal of Physics 41:863-870.

Wilson, J.T. 1965. A new class of faults and their bearing on continental drift. Nature 207(4995):343-347.

Winterer, E.L., and D.T. Sandwell. 1987. Evidence from en-echelon cross-grain ridges for tensional cracks in the Pacific Plate. Nature 329(6139):534-537.

Wolfe, C.J., S.C. Solomon, G. Laske, J.A. Collins, R.S. Detrick, J.A. Orcutt, D. Bercovici, and E.H. Hauri. 2009. Mantle shear-wave velocity structure beneath the Hawaiian hot spot. Science 326(5958):1,388-1,390, doi:10.1126/ science.1180165.

Ye, S., J.P. Canales, R. Rihm, J.J. Danobeitia, and J. Gallart. 1999. A crustal transect through the northern and northeastern part of the volcanic edifice of Gran Canaria, Canary Islands. Journal of Geodynamics 28(1):3-26.

Zindler, A., and S. Hart. 1986. Chemical geodynamics. Annual Review Earth and Planetary Sciences 14:493-571.

Zindler, A., E. Jagoutz, and S. Goldstein. 1982. Nd, Sr and $\mathrm{Pb}$ isotopic systematics in a three-component mantle: A new perspective. Nature 298:519-523.

Zindler, A., H. Staudigel, and R. Batiza. 1984. Isotope and trace element geochemistry of young Pacific seamounts: Implications for the scale of upper mantle heterogeneity. Earth and Planetary Science Letters 70:175-195. 